\title{
Hydrochemical determination of source water contributions to Lake Lungo and Lake Ripasottile (central Italy)
}

\author{
Claire ARCHER, ${ }^{1 *}$ Paula NOBLE, ${ }^{1}$ David KREAMER,${ }^{2}$ Vincenzo PISCOPO,${ }^{3}$ Marco PETITTA,${ }^{4}$ Michael R. ROSEN,${ }^{5}$ \\ Simon R. POULSON, ${ }^{1}$ Gianluca PIOVESAN, ${ }^{6}$ Scott MENSING ${ }^{7}$
}

\begin{abstract}
${ }^{1}$ Department of Geological Sciences and Engineering, University of Nevada, 1664 N. Virginia Street, MS 0172, Reno, NV 89557, USA; ${ }^{2}$ Department of Geoscience, University of Nevada, 505 S Maryland Pkwy, Las Vegas, NV 89154, USA; ${ }^{3}$ Department of Biological and Ecological Sciences, Tuscia University, Loc. Riello snc, 01100 Viterbo, Italy; ${ }^{4}$ Department of Earth Sciences, Sapienza University of Rome, Piazzale A. Moro 5, 00185 Rome, Italy; ${ }^{5}$ United States Geological Survey, 2730 N. Deer Run Road, Carson City, NV 89701, USA; ${ }^{6}$ Department of Sciences and Technology for Agriculture, Forest, Environment and Energy, Tuscia University, Via San Camillo de Lellis snc, 01100 Viterbo, Italy; ${ }^{7}$ Department of Geography, University of Nevada, 1664 N. Virginia Street, Reno, NV 89557, USA *Corresponding author: claire.archer2@gmail.com
\end{abstract}

\begin{abstract}
Lake Lungo and Lake Ripasottile are two shallow (4-5 m) lakes located in the Rieti Basin, central Italy, that have been described previously as surface outcroppings of the groundwater table. In this work, the two lakes as well as springs and rivers that represent their potential source waters are characterized physio-chemically and isotopically, using a combination of environmental tracers. Temperature and $\mathrm{pH}$ were measured and water samples were analyzed for alkalinity, major ion concentration, and stable isotope $\left(\delta^{2} \mathrm{H}, \delta^{18} \mathrm{O}, \delta^{13} \mathrm{C}\right.$ of dissolved inorganic carbon, and $\delta^{34} \mathrm{~S}$ and $\delta^{18} \mathrm{O}$ of sulfate) composition. Chemical data were also investigated in terms of local meteorological data (air temperature, precipitation) to determine the sensitivity of lake parameters to changes in the surrounding environment. Groundwater represented by samples taken from Santa Susanna Spring was shown to be distinct with $\mathrm{SO}_{4}{ }^{2-}$ and $\mathrm{Mg}^{2+}$ content of 270 and $29 \mathrm{mg} / \mathrm{L}$, respectively, and heavy sulfate isotopic composition $\left(\delta^{34} \mathrm{~S}=15.2 \%\right.$ and $\left.\delta^{18} \mathrm{O}=10 \%\right)$. Outflow from the Santa Susanna Spring enters Lake Ripasottile via a canal and both spring and lake water exhibits the same chemical distinctions and comparatively low seasonal variability. Major ion concentrations in Lake Lungo are similar to the Vicenna Riara Spring and are interpreted to represent the groundwater locally recharged within the plain. The $\delta^{13} \mathrm{C}_{\mathrm{DIC}}$ exhibit the same groupings as the other chemical parameters, providing supporting evidence of the source relationships. Lake Lungo exhibited exceptional ranges of $\delta^{13} \mathrm{C}_{\mathrm{DIC}}( \pm 5 \%)$ and $\delta^{2} \mathrm{H}, \delta^{18} \mathrm{O}( \pm 5 \%$ and $\pm 7 \%$, respectively), attributed to sensitivity to seasonal changes. The hydrochemistry results, particularly major ion data, highlight how the two lakes, though geographically and morphologically similar, represent distinct hydrochemical facies. These data also show a different response in each lake to temperature and precipitation patterns in the basin that may be attributed to lake water retention time. The sensitivity of each lake to meteorological patterns can be used to understand the potential effects from long-term climate variability.
\end{abstract}

Key words: Limnology; hydrochemistry; stable isotopes; central Italy.

Received: September 2016. Accepted: November 2016.

\section{INTRODUCTION}

The low water volume and lack of buffering potential in some small lakes (surface area $<0.5 \mathrm{~km}^{2}$ ) can make them particularly sensitive to changes in local environmental conditions and a potential resource for paleohydrologic reconstruction (Wetzel, 2001; Cohen, 2003). However, the contribution of groundwater to the overall water budget of small lakes is often overlooked or underrepresented (Wetzel, 2001; Perini et al., 2009; Rosenberry and Lewandowski, 2015). Lake Lungo and Lake Ripasottile, located in the Rieti Plain (central Italy), are small water bodies that have experienced recent eutrophication (Franceschini et al., 2004). These lakes are of particular interest because of their location within a nature reserve, Riserva Naturale dei Laghi Lungo e Ripasottile (hereafter referred to as Riserva), which was established in 1985 (Franceschini et al. 2004). Previous studies on the hydrology of the Rieti Plain suggest a combination of inputs from groundwater and drainage from manmade irrigation channels (Franceschini et al. 2004; Martarelli et al. 2008). The unknown magnitude and seasonality of these surficial inputs create a challenging scenario for quantifying the lakes' water budgets. Major ions and environmental isotopes as tracers can provide a means for building a conceptual model of water contributions and connectivity. This methodology has been previously used to study neighboring groundwater systems in the intermontane basins of the central Apennines (Petitta et al., 2011, Carucci et al., 2012; Sappa et al. 2012; Tassi et al, 2012; Tallini et al., 2014), as well as groundwater-surface water interactions in other regions (Gourcy and Brenot 2011; Sacks et al., 2014). 
The aim of this study is to gain a better understanding of hydrologic connectivity between the two lakes in the Riserva, to the nearby surface water, as well as to local and regional aquifers. The definition of inputs into each lake will serve two major purposes.

First, it will allow for more informed conservation management practices, particularly in response to a changing climate. To this end, a hydrochemical approach using major ion concentrations and stable isotopes was chosen in this system where physical measurements of surface inflow and outflows are a less informative method. This method can show temporal variations when no physical monitoring equipment is in place, as in the case of these lakes. It also can define the commonly overlooked groundwater influence on lake water budget without directly studying subsurface hydrology. The second purpose of this study is to use the modern characterization of inputs to make informed interpretations of paleolimnology of this system and regional paleoclimate going back three millennia, as part of an ongoing study of lake cores from the Riserva (Mensing et al., 2015). Before the interpretation of geochemical, paleoecological and isotopic signals in the cores, it is necessary to determine what factors in the lake and catchment area drive modern changes in these parameters.

The past few decades in the Mediterranean region, and particularly central Italy, were marked by decreases in both total precipitation and number of wet days (Brunetti et al. 2012; Carucci et al. 2012). Regional karstic aquifers in this region, hosted in the carbonate ridges, have already experienced decreases in storage and associated spring discharge (Di Matteo and Dragoni, 2006; Fiorillo et al., 2015). The Santa Susanna Spring, for instance, discharging the basal flow of the regional carbonate aquifer located to the northeast of the study area (Fig. 1), has experienced a 30\% reduction in recharging water over the past several decades (Spadoni et al. 2010). The warming trend observed in Italy over the last approximately 40 years, especially the significant increases in summer temperatures (Fioravanti et al. 2015), combined with agricultural demand for water in the basin (Massarutto, 1999) will also likely impact water supply to these lakes. Changes in precipitation and air temperature associated with local impacts of predicted global climate change are the primary parameters of concern as they directly and indirectly affect water supply. Without access to groundwater data, this study was limited to postulating the impacts of meteorological trends and looking for evidence of a limnological response. The relationship between these trends and the within-lake conditions was assessed by examining correlations of lake chemical and physical measurements with local meteorological data for the same period. This lake-sensitivity analysis may also help predict how these protected and significant water bodies will react to future shifts in temperature or precipitation.
Informed management of these lakes, for wildlife conservation, water quality and water supply, is dependent on an overall better understanding of hydrology in the Rieti Basin.

\section{Regional geologic, hydrogeological, and climatic setting}

The Rieti Basin is an intermontane depression located in the central Apennine thrust system (Fig. 1). Recently uplifted marine sediments, comprised primarily of limestone, characterize the geology of this region. During the Miocene, compressional tectonics forced pelagic carbonate sequences upwards above sea level (Cosentino et al., 2010). Extensional tectonics dominate in the region since the Upper Pliocene - Lower Pleistocene, forming basins such as Rieti that subsequently aggraded with clastic lacustrine and alluvial deposits (Cavinato and De Cellis, 1999). The Rieti Basin remains seismically active and deep normal faults mark the boundaries between the Meso-Cenozoic carbonate ridges and the recent continental deposits on the northern, western and eastern edges of the plain. The recent plain-filling alluvial unit ranges in thickness from $80 \mathrm{~m}$ on the eastern side of the plain to over $400 \mathrm{~m}$ on the western side (Martarelli et al., 2008).

Carbonate ridges hosting regional aquifers (Boni et al., 1986) characterize the hydrogeology of the central Apennines. Discharge occurs at their contact with less permeable units and yields springs with high flow (up to $18 \mathrm{~m}^{3} \mathrm{~s}^{-1}$ ). Normal faults at the border of the plain separating these two units also serve as a conduit for groundwater to travel to the surface and discharge at springs. The hydrogeology of the Rieti Plain, studied and mapped by Martarelli et al. (2008) and Capelli et al. (2012), is characteristic of the Apennine tectonic basin flow regime, where the regional flow system is hosted by the surrounding carbonate bedrock and a shallower layered aquifer exists within the more recent alluvium deposits filling the plain $(\mathrm{k})$. These plain-filling deposits are low permeability PleistoceneHolocene fluvial and lacustrine sediment interbedded with gravelly colluvium and occasional peat layers. The makeup of this unit creates a scenario where local recharge is relatively limited if compared with that of the surrounding carbonate aquifers and groundwater flow mainly occurs in the coarser grained units or at the contacts between the beds (Martarelli et al. 2008; Capelli et al., 2012). At the northeastern edge, the Santa Susanna Spring (hereafter referred to as SUS) (Tab. 1) represents the highest discharge spring of those in direct contact with the plain as well as the baseflow of the regional aquifer (Zuppi and Bortolami, 1982). This regional aquifer is hosted in the Terminillo and Reatini mountain carbonate aquifer units to the east and the spring emerges at the intersection of two normal faults bounding this unit (Martarelli et al., 2008; Spadoni et al., 2010). Mesozoic evaporites comprise a portion of this carbonate 
unit, underlain at the base by Triassic dolomites (Capelli et al., 2012).

The Vicenna Riara Spring (hereafter referred to as VIC) (Tab. 1) is distinct among springs included in this study because of its location near the center of the plain, about $0.8 \mathrm{~km} \mathrm{SSE}$ of Lake Lungo. Water flows to this spring along a buried fault and through preferential flowpaths within the Pleistocene conglomeratic alluvial deposits that lie in the central-eastern part of the plain (Martarelli et al., 2008).

The Velino River (Fig. 1) represents the major portion of surface water flowing into the plain $\left(35 \mathrm{~m}^{3} \mathrm{~s}^{-1}\right.$, Tab.1; the Turano and the Salto Rivers enter the plain at $2 \mathrm{~m}^{3}$ $\mathrm{s}^{-1}$ and $1 \mathrm{~m}^{3} \mathrm{~s}^{-1}$, respectively, and converge with the Velino River). Velino's waters are sourced upstream to the south- east from the regional carbonate aquifer. Here, at its headwaters, the river acts as a linear spring, discharging groundwater from the regional aquifer (Petitta, 2009). Downstream of this, and within the Rieti Plain, the river is mostly a losing stream, with its water contributing to the alluvial aquifer of the plain.

Located about $8 \mathrm{~km}$ upstream from the Rieti Plain in the Velino River Valley, the San Vittorino Plain holds several springs that discharge in the same manner as SUS, where large discharges occur at the contact between carbonate units and plain-fill deposits. Two of these springs were sampled in this study, the Peschiera and the Terme di Cotilia springs (hereafter referred to as PES and COT, respectively) (Fig. 1). These localities were included because of their large discharge (Tab. 1) and potential con-

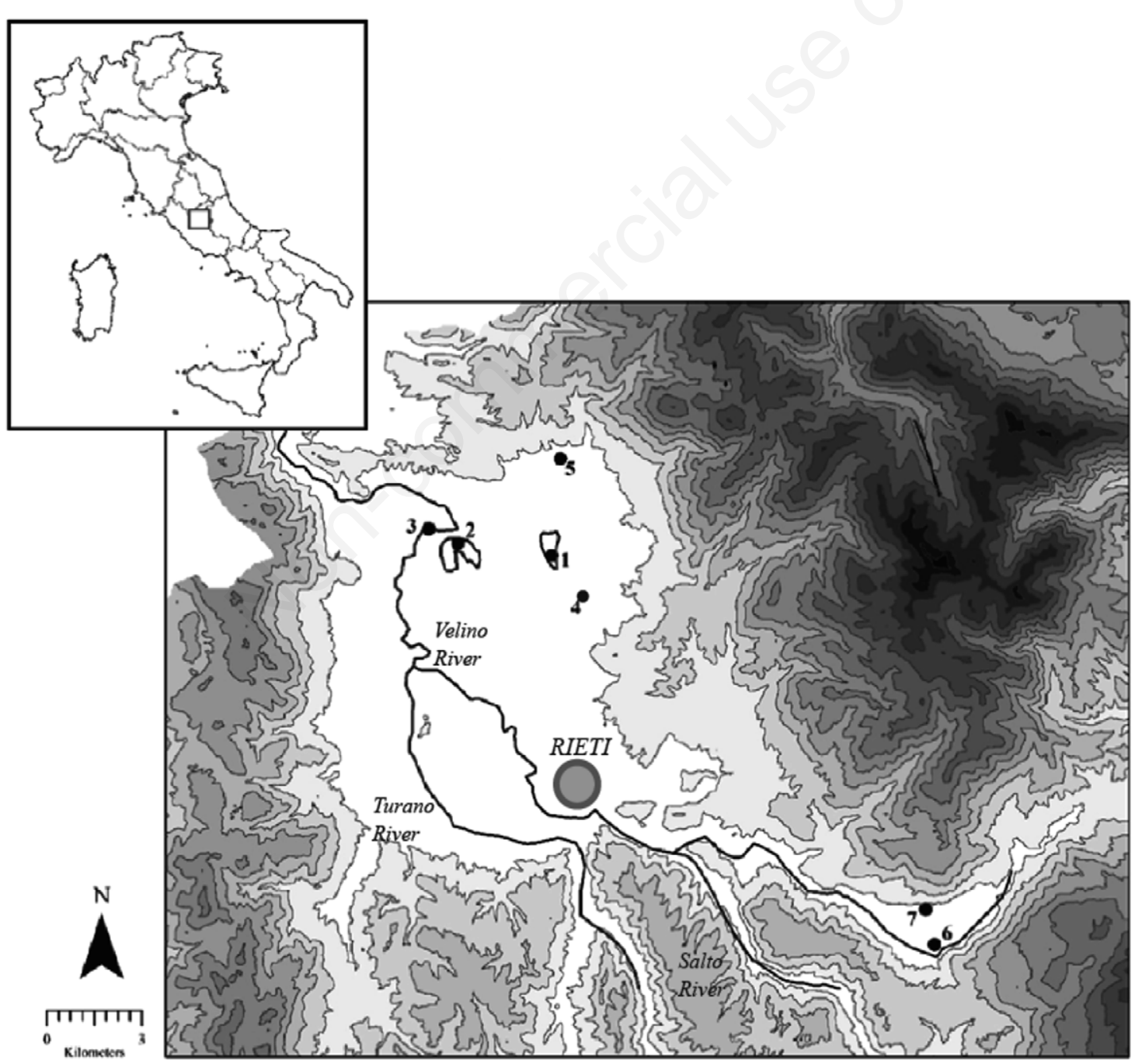

Fig. 1. Map of study area. Black dots indicate sampling localities. Elevations contours show 150 meter intervals. Numbers correspond to names given in Tab. 1: 1, Lake Lungo (LUN); 2, Lake Ripasottile (RIP); 3, Velino River (VRV); 4, Vicenna Riara Spring (VIC); 5, Santa Susanna Spring (SUS); 6, Peschiara Spring (PES); 7, Cotilia di Terme Spring (COT). 
tribution to the waters of the Rieti Plain. Previous hydrochemical investigations were also conducted on these waters, allowing the limited number of samplings from this study to fit into a greater context. Local research has also focused on Lake Paterno, a sinkhole lake located in the S. Vittorino Plain with a similar geologic setting to Lake Lungo and Ripasottile (Tassi et al. 2012). Many of the previous studies on groundwater in this area focused in part on how tectonic discontinuities allow deep, mineralized fluids to migrate up and mix with regional aquifer water, as in the case of COT, and to mix with lake water, as in the case of Lake Paterno (Zuppi and Bortolami, 1982; Petitta et al., 2011; Tassi et al., 2012). PES, with the highest discharge in the study area (i.e., $18 \mathrm{~m}^{3} \mathrm{~s}^{-1}$ ), represents a major drinking water supply to Rome. The groundwater contribution to the spring is mainly from the aquifer hosted within the uplifted carbonate shelf deposits to the ESE, in bedrock consisting of Triassic-Paleocene limestone located in the Giano-Nuria mountains (Petitta, 2009; Civita and Fiorucci, 2010).

The surface water hydrology of the Rieti Plain is complicated by the extensive human alteration of the landscape and waterways (Franceschini et al., 2004; Martarelli et al., 2008). Prior to human modification, the plain was occupied by one large lake, Lacus Velinus, until approximately the Roman Era, when a combination of human land-reclamation efforts and climate change decreased the area and water level of the lake. The area was modified to its current configuration in the 1930's, when canal construction and drainage efforts removed excess surface water (Calderoni et al., 1994; Martarelli et al., 2008). Presently, a network of canals and ditches drains water from nearby springs and agricultural land into wetlands surrounding both Lake Lungo and Ripasottile (hereafter referred to as LUN and RIP). RIP also receives inflowing water from an artificial channel from the nearby SUS. This water flows from the spring then is diverted through a fish farm before flowing into the RIP. The magnitude of SUS as a water source and its impact on RIP's water balance was not previously studied. Another artificial channel connects RIP to the wetlands on the west end of LUN. The level of the lakes is main- tained by a pumping station located at the northwest corner of RIP where effluent is directed into the Velino River. This prevents the lake depths from increasing and maintains a scenario where the shallow lakes' water columns continue to mix throughout the year without a prolonged period of stratification.

The Rieti Basin experiences climate with typical Mediterranean precipitation patterns, characterized by the majority of precipitation occurring in autumn and winter (Supplementary Tab. 1), with relatively arid summers (Combourieu-Nebout et al., 2015). Within Italy, the Rieti Plain lies in the climate region categorized as the warm temperate mountainous zone based on the continentality (seasonal shifts) of annual temperatures, the mean annual precipitation, and the potential evapotranspiration (Costantini et al., 2013). The mean monthly temperature in this area varies between $4^{\circ} \mathrm{C}$ in January and $21{ }^{\circ} \mathrm{C}$ in July (Leone, 2004). Studies based on long-term records prior to the $21^{\text {st }}$ century found the annual mean precipitation at $1117 \mathrm{~mm}$ (Leone, 2004), though the mean annual precipitation from 2003-2015 collected from gauges in Rieti was 1013 mm (Supplementary Tab. 1).

\section{METHODS}

\section{Data compilation}

Monthly data collected by the regional environmental protection agency, ARPA Lazio, from 2010-2015 regarding lake temperature, $\mathrm{pH}$, alkalinity, conductivity, and major ion concentrations were compiled. Monthly mean temperature data and total precipitation data over the sampling period were extracted and tabulated from annual records published on the website of the Ufficio Idrografico e Mareografico, Lazio (Supplementary Tabs. 1-4).

Another dataset of lake physio-chemical parameters collected by ARPA Lazio between 2010 and 2015 was also included in the present study with data collected between 2010-2015. These data, although not continuous, serve as a high-resolution record of near monthly lake

Tab. 1. Geographic and limnologic characteristics of the study sites.

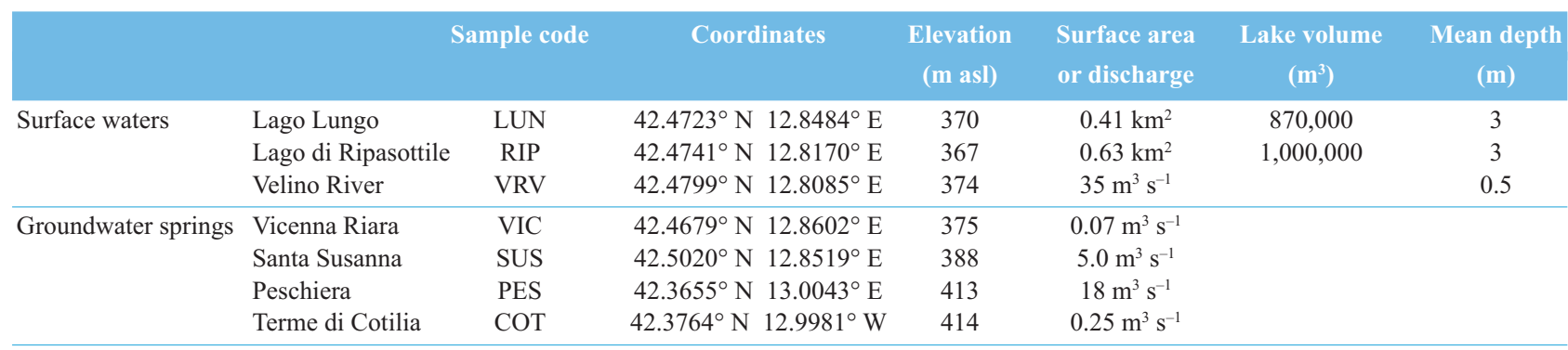


temperature, alkalinity, $\mathrm{pH}$, and conductivity over several years. Major ion concentration data for the two lakes was available monthly for one year (2011).

\section{Sample collection}

Field surveys and sample collection for this study were conducted five times over a 15-month period during the following months: June 2014, July 2014, February 2015, May 2015 and September 2015. At each lake locality (1 and 2 in Fig. 1), samples were collected from the center of the lake at the median depth in the water column using a Van Dorn sampler (Priscu and Dodds, 1988). Physical parameters (temperature, $\mathrm{pH}$, electrical conductivity) were measured on-site using a Yellow Springs Instrument $\left(\mathrm{YSI}^{\circledR}\right) 85$ multi-parameter sensor and an Oakton ${ }^{\circledR} \mathrm{pH}$ meter. Water samples were filtered on-shore using a $0.45 \mu \mathrm{m}$ Millipore filter, then alkalinity was measured by titrating with $1.6 \mathrm{~N}$ sulfuric acid to a $\mathrm{pH}$ endpoint of 4.5. Replicate analysis of samples for alkalinity showed that the standard deviation from the mean was within 5\%. The remaining filtered samples were stored in high-density polyethylene (HDPE) bottles with no head space, then one aliquot was placed in a $10-\mathrm{mL}$ glass vial for stable isotopic analysis of oxygen and hydrogen in water. During subsequent storage and transport of samples, a temperature of $4.5^{\circ} \mathrm{C}$ was maintained.

The Velino River (hereafter referred to as VRV; 3 in Fig. 1) was sampled 1 meter from shore, at the depth halfway between the channel surface and bottom. At each spring locality (4. 5, 6 and 7 in Fig. 1), samples were collected as close as possible to the discharge point. All subsequent procedures for sample collection and physical parameter measurement were identical to those described above for the lake localities.

\section{Lake surveys}

During the May 2015' field season, surveys of LUN and RIP were conducted to quantify lake bathymetry and to explore the potential for groundwater flow or seepage at the lake perimeter. A handheld sonar system (Hawkeye $\mathrm{H} 22 \mathrm{PX}$ ) was used to determine water depth along transects, and a GPS (global positioning system) unit was used to record position. The depth data from these transects were used to calculate lake volume by creating a triangulated irregular network (TIN) in ArcGIS 10.4 $\left(\mathrm{ESRI}^{\circledR}\right)$. The YSI sensor was also used to survey temperature at 24 points along the LUN perimeter $(<1 \mathrm{~m}$ water depth) and 48 points at RIP perimeter. Volumetric flow rate in the channel connecting the two lakes and in the artificial channel originating at SUS and entering RIP was determined by measuring channel cross sectional area then multiplying by average flow velocity.

\section{Analyses}

Major ion concentrations of all samples were determined using ICP-MS and ICP-OES at the Western Environmental Testing Laboratory in Sparks, NV, USA. Samples were prepared by trace metals digestion using U.S. EPA method 200.2 (Martin et al., 1994). Chloride and sulfate were analyzed using EPA method 300.0 (Pfaff, 1993) and all other ions using EPA method 200.7 (Maxfield and Mindak, 1985). The accuracy was controlled by using internal laboratory standards prior to every sample run, after every tenth sample, and immediately following a sample run. Replicate analysis of one field duplicate, one analytical duplicate sample and two laboratory standards per sample collection date showed that the precision was within 5\%.

Waters were prepared for isotopic analysis by precipitation of dissolved sulfate as $\mathrm{BaSO}_{4}$ following the method of Carmody et al. (1998). $\mathrm{BaSO}_{4}$ precipitates were analyzed for $\delta^{34} \mathrm{~S}$ using $\mathrm{V}_{2} \mathrm{O}_{5}$ as a combustion aid, and followed the methods of Giesemann et al. (1994) and Grassineau et al. (2001). $\mathrm{BaSO}_{4}$ precipitates were analyzed for $\delta^{18} \mathrm{O}$ following the method of Kornexl et al. (1999). The analytical error, estimated by replicate analysis, was $\pm 0.2 \%$ and \pm 0.4 $\%$ for $\delta^{34} \mathrm{~S}$ and $\delta^{18} \mathrm{O}$ of dissolved sulfate, respectively. Water samples were prepared for isotopic analysis of dissolved inorganic carbon by precipitation as $\mathrm{SrCO}_{3}$ after the method of Usdowski et al. (1979), and then analyzed using the method of Harris et al. (1997), with analytical error within $\pm 0.2 \%$. Waters were analyzed for $\delta^{18} \mathrm{O}$ using the $\mathrm{CO}_{2}-\mathrm{H}_{2} \mathrm{O}$ equilibration method of Epstein and Mayeda (1953), and for $\delta^{2} \mathrm{H}$ using the method of Morrison et al. (2001). The analytical error of these measurements was $\pm 0.1 \%$ and $\pm 1.0 \%$ or for $\delta^{18} \mathrm{O}$ and $\delta^{2} \mathrm{H}$, respectively. All stable isotope analyses were carried out at the University of Nevada, Reno. All values are reported using delta notation $(\delta \%)$, and the standards used were V-SMOW for oxygen and hydrogen, V-PDB for carbon and V-CDT for sulfur.

Descriptive statistics of the local meteorological data (mean temperature and total precipitation; Supplementary Tabs. 1 and 2) and records of lake physical and chemical parameters were calculated initially to confirm a normal distribution of the data. Correlation between these data sets was then investigated using the Pearson product-moment correlation. This analysis, and all r-values, were calculated using the Excel Data Analysis tool pack and values are displayed in correlograms. The significance of these correlations was determined using the table of critical values for Pearson's r. The significance level of correlations is indicated by the degree of shading in the correlograms.

Saturation indices for calcite, anhydrite and gypsum were calculated using the program PHREEQC for Windows, version 2.16.02 (Parkhurst and Appelo, 1999). PHREEQC was also used to simulate mixing between select waters. 


\section{RESULTS}

\section{Physical-chemical parameters}

Physical-chemical data collected during the sampling period (Tab. 2) were compiled with meteorological and physical-chemical data for the two lakes that were collected over a longer time period by ARPA, Lazio. Major ion concentration data collected and analyzed by ARPA were also available monthly for 2011 . The data collected during this study $(2014,2015)$ fall within the range of values observed for previous years (2010-2015). The local meteorological data (mean monthly temperature, total monthly precipitation; Supplementary Tabs. 1 and 2) were used to test the sensitivity of the two lakes to changes in local climate factors over short (monthly) time scales.

Lake surveys yielded updated lake bathymetric data that were used to calculate lake volume. The maximum depth in LUN was $4.5 \mathrm{~m}$ and in RIP was $4.2 \mathrm{~m}$. These results contrasted with previous studies on the lakes' physiography that found a maximum depth in LUN of $7.25 \mathrm{~m}$ and in RIP of $7.5 \mathrm{~m}$ (Riccardi, 2006). Physical surveys of the perimeter of LUN yielded no measurable flowing water. These surveys also found that for the measured locations around the perimeter, $\mathrm{LUN}$ temperature variations were $\pm 0.5^{\circ} \mathrm{C}$. In RIP the temperature was $8^{\circ} \mathrm{C}$ colder $\left(10^{\circ} \mathrm{C}\right.$ versus $\left.18^{\circ} \mathrm{C}\right)$ at the entrance of the SUS- diverted channel inflow, but $18 \pm 0.7^{\circ} \mathrm{C}$ along the rest of the perimeter. Physical surveys conducted during July 2014 and May

Tab. 2. Physical and chemical parameters of all waters sampled, including major ion concentrations in $\mathrm{mg} \mathrm{L}^{-1}$. Results of the mixing simulation carried out using PHREEQC are also included.

\begin{tabular}{|c|c|c|c|c|c|c|c|c|c|c|c|c|c|}
\hline & $\begin{array}{l}\text { Temperature } \\
\qquad\left({ }^{\circ} \mathrm{C}\right)\end{array}$ & $\begin{array}{l}\text { Conductivity } \\
\qquad(\mu \mathrm{S} / \mathrm{cm})\end{array}$ & $\mathrm{pH}$ & $\mathrm{Cl}^{-}$ & $\mathrm{SO}_{4}^{2-}$ & $\begin{array}{c}\mathrm{HCO}_{3}^{-} \\
\text {(from alkalinity) }\end{array}$ & $\mathrm{Na}^{2+}$ & $\mathrm{Mg}^{2+}$ & $\mathbf{K}^{+}$ & $\mathrm{Ca}^{2+}$ & $\mathrm{SI}_{\text {calcite }}$ & $\mathbf{S I}_{\text {anhyd }}$ & $\mathrm{SI}_{\mathrm{gyps}}$ \\
\hline \multicolumn{14}{|l|}{ SUS } \\
\hline 2015-September & 10.4 & 855 & 7.3 & 3.6 & 270 & 275 & 2.9 & 30 & 0.55 & 140 & 0.18 & -1.5 & -1.0 \\
\hline 2015-May & 10.3 & 798 & 7.1 & 3 & 260 & 235 & 2.8 & 29 & 0.68 & 130 & -0.1 & -1.5 & -1.0 \\
\hline 2015-February & 10.7 & 851 & 7.6 & 3.7 & 280 & 296 & 2.6 & 30 & 0.56 & 120 & 0.53 & -1.5 & -1.0 \\
\hline 2014-July & 10.9 & 835 & 7.4 & 3.7 & 270 & 266 & 2 & 27 & 0 & 110 & 0.13 & -1.5 & -1.0 \\
\hline \multicolumn{14}{|l|}{ VIC } \\
\hline 2015-September & 12.2 & 520 & 7.4 & 6.7 & 7 & 304 & 5.3 & 2 & 1.2 & 95 & 0.29 & -3.0 & -2.6 \\
\hline 2015-May & 13.2 & 506 & 7 & 6.6 & 6.8 & 299 & 5.2 & 2.1 & 1.7 & 94 & 0 & -3.0 & -2.6 \\
\hline 2015-February & 13 & 527 & 7.4 & 4.8 & 10 & 357 & 3 & 2.1 & 0.78 & 100 & 0.38 & -2.9 & -2.4 \\
\hline 2014-July & 13 & 534 & 7.3 & 5.5 & 6.3 & 292 & 4.2 & 2 & 1.2 & 96 & 0.16 & -3.0 & -2.6 \\
\hline \multicolumn{14}{|l|}{ PES } \\
\hline 2015-September & 12.4 & 597 & 7.2 & 4 & 6.8 & 411 & 4.4 & 18 & 1.1 & 100 & 0.22 & -3.1 & -2.6 \\
\hline 2015-May & 11.4 & 594.8 & 7 & 3.4 & 8.9 & 409 & 3.1 & 19 & 0.84 & 100 & -0.44 & -3.0 & -2.5 \\
\hline 2015-February & 10 & 653 & 7 & 7 & 6.8 & 540 & 4.9 & 20 & 1.2 & 100 & 0.09 & -3.1 & -2.6 \\
\hline 2014-July & 12.8 & 617 & 7.2 & 4.1 & 8.4 & 404 & 2.6 & 19 & 0.8 & 94 & 0.12 & -3.0 & -2.6 \\
\hline \multicolumn{14}{|l|}{ COT } \\
\hline 2015-September & 14.6 & 2024 & 5.6 & 22 & 130 & 1534 & 18 & 56 & 3.7 & 340 & -0.44 & -1.6 & -1.2 \\
\hline 2015-May & 14.2 & 1925 & 5.7 & 17 & 130 & 1183 & 17 & 55 & 3.8 & 340 & 0.37 & -1.6 & -1.1 \\
\hline 2015-February & 12.4 & 2040 & 6 & 23 & 150 & 1721 & 16 & 58 & 3.3 & 350 & -0.03 & -1.5 & -1.1 \\
\hline \multicolumn{14}{|l|}{ RIP } \\
\hline 2015-September & 16.2 & 792 & 8 & 5.5 & 220 & 201 & 3.5 & 28.5 & 0.86 & 130 & 0.8 & -1.5 & -1.1 \\
\hline 2015-May & 18 & 837 & 7.5 & 3.5 & 210 & 232 & 3.2 & 26 & 0.87 & 120 & 0.08 & -1.5 & -1.2 \\
\hline 2015-February & 10.1 & 755 & 8.4 & 5.4 & 190 & 333 & 3.6 & 25 & 0.86 & 120 & 1.28 & -1.6 & -1.2 \\
\hline 2014-July & 17.8 & 760 & 8.2 & 5.5 & 210 & 239 & 2.7 & 23 & 0 & 100 & 0.96 & -1.6 & -1.2 \\
\hline \multicolumn{14}{|l|}{ LUN } \\
\hline 2015-September & 19.6 & 517 & 7.9 & 7.4 & 11.4 & 240 & 7.6 & 7.1 & 1.8 & 105 & 0.83 & -2.7 & -2.4 \\
\hline 2015-May & 22.8 & 419.5 & 7.6 & 8.7 & 9.3 & 220 & 8.6 & 5 & 1 & 58 & 0.34 & -3.0 & -2.6 \\
\hline 2015-February & 10.3 & 666 & 7.7 & 8.7 & 21 & 384 & 7.1 & 6.4 & 1.5 & 110 & 0.69 & -2.6 & -2.8 \\
\hline 2014-July & 20.1 & 587 & 8 & 6.8 & 9.9 & 307 & 5.6 & 4.9 & 1 & 84 & 0.94 & -2.8 & -2.5 \\
\hline \multicolumn{14}{|l|}{ VRV } \\
\hline 2015-September & 12.8 & 789 & 7 & 9.7 & 32 & 546 & 5.4 & 24 & 1.2 & 108 & 0.15 & -2.4 & -2.0 \\
\hline 2015-May & 12.4 & 798 & 6.9 & 5.8 & 27 & 534 & 5.4 & 20 & 1.3 & 20 & -0.07 & -2.4 & -2.0 \\
\hline 2015-February & 9.2 & 613 & 8.7 & 9.2 & 20 & 549 & 6.2 & 14 & 1.3 & 91 & 1.66 & -2.7 & -2.2 \\
\hline 2014-July & 12.7 & 769 & 7.5 & 9.4 & 27 & 470 & 6.2 & 20 & 1.2 & 110 & 0.5 & -2.5 & -2.0 \\
\hline $\begin{array}{l}\text { MIX 80:20\% SUS:LUN } \\
\text { (PHREEQC simulation) }\end{array}$ & 4.3 & 218 & 275 & 2.7 & 23 & 0.2 & 105 & 0.28 & -1.6 & -1.3 & & & \\
\hline
\end{tabular}


2015 indicated a flow velocity of close to zero in the channel between the two lakes. The volumetric flow rate of the diverted channel entering RIP was approximately 1 $\mathrm{m}^{3} \mathrm{~s}^{-1}$ during May 2015 and September 2015. Lake surface area and volume in LUN was calculated at 413,000 $\mathrm{m}^{2}$ and $870,000 \mathrm{~m}^{3}$, respectively (Tab. 1). In RIP, surface area is $626,000 \mathrm{~m}^{2}$ and volume is $1,000,000 \mathrm{~m}^{3}$.

Correlation matrices (Figs. 2 and 3) display how the physical and chemical parameters may be influenced by meteorological data (temperature, precipitation) at lakes LUN and RIP. The stronger r-values (those approaching 1 or -1 ), indicated by the degree of shading in the box, were observed between LUN water temperature and average monthly air temperatures $(0.92)$. Other notably high correlations $(r>0.75, r<-0.75)$ were found between LUN nitrate concentration and sulfate, calcium, and air temperature, as well as RIP sulfate and potassium concentration. RIP shows less correlation between air and lake water temperature $(\mathrm{r}=0.64)$ than $\mathrm{LUN}$, but a potentially negative correlation between air temperature and alkalinity $(\mathrm{r}=-0.7)$. In LUN, temperature compared to nitrate, sulfate, and calcium concentrations exhibited high values, while in RIP the only ion that may correlate with temperature was nitrate.

Results of the PHREEQC geochemical modeling of the saturation index of the lakes and spring waters with respect to calcite $\left(\mathrm{SI}_{\text {calcigte }}\right)$ shows that the lakes (RIP, LUN) had consistently positive values throughout the sampling period (Tab. 2). The other sites were variable throughout the year, ranging from -0.44 at COT (September 2015) to +1.28 at RIP (February 2015). All samples were undersaturated with respect to gypsum and anhydrite $\left(\mathrm{SI}_{\text {gypsum }}, \mathrm{SI}_{\text {anhydrite }}<-1\right)$.

The major ion data collected and analyzed during 2014-2015 (Tab. 2, Fig. 4) were used in the delineation of two main hydrochemical facies in the study region: $\mathrm{Ca}-$ $\mathrm{HCO}_{3}^{-}$type water and $\mathrm{Ca}-\mathrm{HCO}_{3}{ }^{-} \mathrm{SO}_{4}$. SUS and RIP represent the $\mathrm{Ca}-\mathrm{HCO}_{3}-\mathrm{SO}_{4}$ facies, whereas VIC and LUN represent the $\mathrm{Ca}-\mathrm{HCO}_{3}{ }^{-}$facies. VIC and $\mathrm{LUN}$ are also distinct in their slightly elevated $\mathrm{Na}^{+}$and $\mathrm{K}^{+}$relative to the

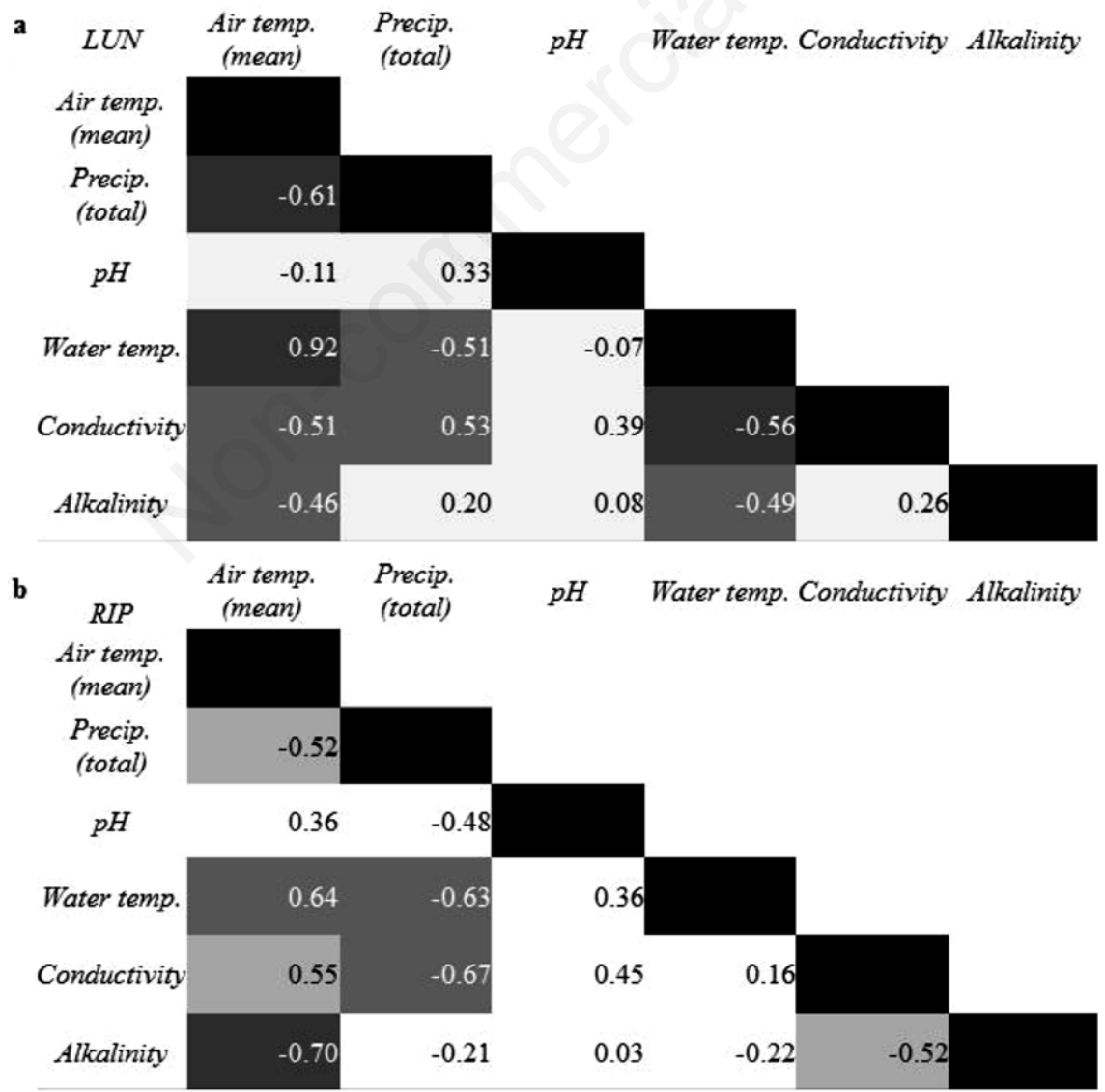

Fig. 2. Correlograms of lake physical parameters and local meteorological data in a. LUN and b. RIP, during each season over the years 2010-2015. Values of the correlation coefficient (r) are displayed, while shading denotes the level of significance (p). Black denotes the most significant linear correlation and white denotes not a significant correlation; the null hypothesis cannot be rejected. 
other waters. Additionally, a third facies can be categorized as the high-TDS $\mathrm{Ca}^{2+}-\mathrm{HCO}_{3}{ }^{-}$type exemplified by COT, with average TDS values almost four times that of the other samples.

\section{Stable isotopes}

The $\delta^{2} \mathrm{H}$ and $\delta^{18} \mathrm{O}$ composition of the waters sampled ranged from -58 to $-37 \%$ and -9.0 to $-5.3 \%$, respectively (Fig. 5 and Tab. 3). Samples generally fall along the central Italian Meteoric Water Line (cIMWL) calculated by Longinelli and Selmo (2003), with only a few notable exceptions. The major groupings of sites by their position along the local meteoric water line are: i) the samples of three waters with origins upstream from the basin in the Velino River Valley (VRV, PES and COT); ii) SUS and
RIP; iii) LUN and VIC. LUN shows the largest variability of any of the localities' samples. Values of precipitation from rain gauges were also included (locations given in Fig. 1, from Spadoni et al., 2010; Tab. 3) at two different elevations within the study area; the first within the Rieti Plain at $378 \mathrm{~m}$ asl and the second along the carbonate ridge to the east at $1375 \mathrm{~m}$ asl.

The $\delta^{13} \mathrm{C}_{\text {DIC }}$ versus $\mathrm{HCO}_{3}{ }^{-}$concentration shows similar groupings to that of the $\delta^{2} \mathrm{H}$ and $\delta^{18} \mathrm{O}$ data (Tab. 3 and Fig. 6). Samples collected from VRV and PES group together with more enriched $\delta^{13} \mathrm{C}_{\mathrm{DIC}}$ and high concentrations of $\mathrm{HCO}_{3}{ }^{-}$. RIP and SUS again plot together, as do LUN and VIC during February and July 2014. COT plotted separate from all other sites, with comparatively enriched $\delta^{13} \mathrm{C}_{\mathrm{DIC}}$ values of +2.9 to $+4.7 \%$. Little variability was seen in $\delta^{13} \mathrm{C}_{\mathrm{DIC}}$ during the different sampling periods at all

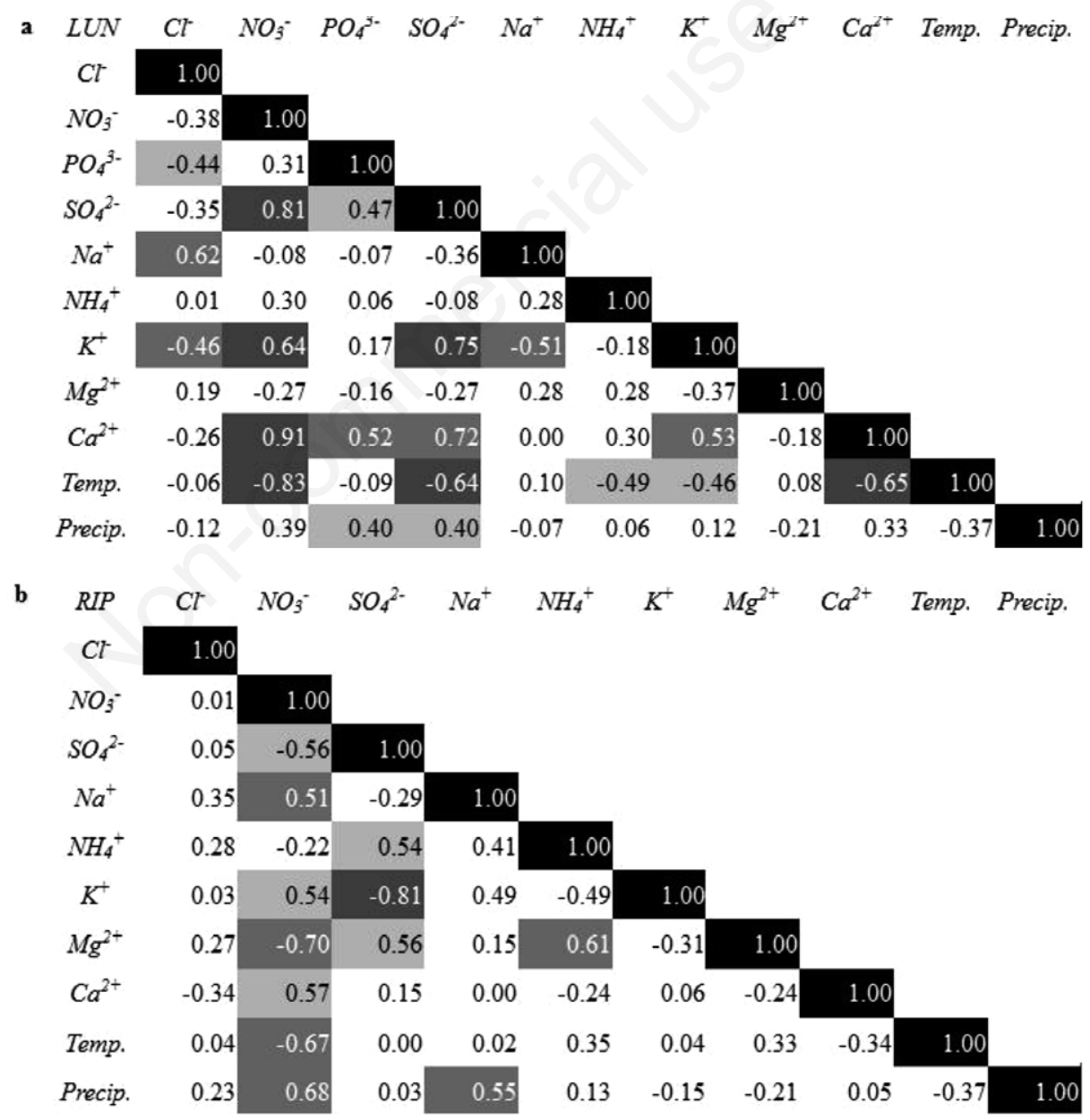

Fig. 3. Correlograms of major ion concentrations in a. LUN and b. RIP for the only year where monthly data was available, 2011. Also included are mean monthly local air temperature and total monthly precipitation during 2011. Shading pattern is the same as in Fig. 2. Major ion concentrations for this time-period were collected and analyzed by ARPA, Lazio. Meteorological data (Temp., Precip.), retrieved from http://www.idrografico.roma.it/, are the monthly mean air temperature or total precipitation from the month when the major ion sample was taken. Phosphate $\left(\mathrm{PO}_{4}^{-}\right)$concentrations were not available for RIP, so are not included in (b.). 
localities, with the exception of LUN. The range in values from LUN was -8.9 to $-13.9 \%$, with the most depleted values in July 2014 and an enrichment observed during May and September 2015. The amount of DIC in each water, represented by the $\mathrm{HCO}_{3}{ }^{-}$concentration, did not change substantially over the sampling period.

$\delta^{34} \mathrm{~S}_{\text {sulfate }}$ and $\delta^{18} \mathrm{O}_{\text {sulfate }}$ ranged from $-9.9 \%$ to $+17.2 \%$, and from $-0.7 \%$ to $+10.8 \%$, respectively. The sites that exhibited the most temporal variability were VIC, LUN, and VRV (Tab. 3). The range of $\delta^{34} \mathrm{~S}_{\text {sulfate }}$ values was $25 \%$, $3.3 \%$, and $5.4 \%$, respectively in VIC, LUN and VRV. The comparison of values in this study with typical ranges of sulfate stable isotope values (Fig. 7) are displayed using the mean values of $\delta^{34} \mathrm{~S}_{\text {sufate }}$ and $\delta^{18} \mathrm{O}_{\text {sulfate }}$ at each locality for all the sampled months.

\section{DISCUSSION}

\section{Hydrologic provenance}

In the central Apennines, recharge elevation is the primary control of oxygen and hydrogen stable isotopic values of groundwater (Zuppi and Bortolami, 1982; Longinelli and Selmo, 2003, Tallini et al., 2014). The waters sampled located in the Velino River Valley, i.e., PES, COT and VRV, have $\delta^{18} \mathrm{O}$ and $\delta^{2} \mathrm{H}$ values that support a high-elevation recharge area. The recharge area for PES is the Velino-Nuria Mountains to the southeast, extending from approximately $415 \mathrm{~m}$ to $2000 \mathrm{~m}$ asl (Petitta, 2009; Civita and Fiorucci, 2010).

The relatively enriched $\delta^{13} \mathrm{C}_{\text {DIC }}$ values of PES, VRV and COT can be attributed to water-rock interactions between groundwater and carbonate shelf deposits and localized dolomites making up the hydrogeological unit hosting the aquifer (Petitta, 2009; Petitta et al., 2011). The VRV is predominantly a gaining stream in the upstream Velino Valley adjacent to PES and COT, where discharge originates from linear springs (Petitta, 2009). The river was sampled, however, downstream in a location where it feeds groundwater of the plain (Martarelli et al., 2008). COT, discharging on the northern edge of the plain, receives groundwater from both the regional carbonate aquifer and gas-rich waters uprising along tectonic discontinuities (Zuppi and Bortolami, 1982; Petitta, 2009). The input of mineralized water from a deep source with extensive water-rock interactions give to this spring its distinct high-dissolved ion signature, low $\mathrm{pH}$, and significantly enriched $\delta^{13} \mathrm{C}_{\text {DIC }}$ values (Tab. 3). Unlike Lake Paterno, as shown by Tassi et al. (2012), however, the lakes of the Rieti Plain do not receive significant contributions from this mineralized spring water. This could be because of the difference in physical proximity to COT and related waters or because of the difference in lake depth (Lake Paterno maximum depth is $>50 \mathrm{~m}$ ) prevents communica- tion of the Rieti Plain lakes with the deep aquifer system.

The recharge occurring in the carbonate unit of the Reatini Mountains to the east of the plain that supplies SUS extends over a broader area and wider range of elevations compared with the springs in the Velino River Valley (Fig. 1, Spadoni et al., 2010), producing the slightly more positive values of SUS compared to these upstream spring samples. The two major springs sampled within the plain, VIC and SUS receive water from two hydrochemically differentiable sources. Evidence for this is seen in the divergence in major ion concentrations (Fig. 4), the stable isotope values (Figs. 5-7), and the difference in flow rate (Tab. 1). The $\delta^{18} \mathrm{O}$ and $\delta^{2} \mathrm{H}$ values of VIC water are heavier than samples from the other springs, indicating a predominant local recharge component with contributions also from infiltration through the alluvial-conglomerate fan unit at the eastern edge of the plain (Fig. 8). The VIC hydrochemistry showed a lack of elevated $\mathrm{SO}_{4}{ }^{2-}$ concentrations and absence of the $\delta^{18} \mathrm{O}_{\text {sulfate }}, \delta^{34} \mathrm{~S}_{\text {sulfate }}$, and $\delta^{13} \mathrm{C}_{\mathrm{DIC}}$ signature that characterizes water from the regional carbonate aquifer. These data indicate that there is not a significant contribution from the regional carbonate aquifer to this spring. Our data indicate that the low-permeability lacustrine and fluvial deposits at the lowest elevations of the plain prevent notable water exchange between this unit and the regional carbonate aquifer unit.

The $\delta^{18} \mathrm{O}_{\text {sulfate }}$ and $\delta^{34} \mathrm{~S}_{\text {sulfate }}$ values of SUS are similar to those of COT, indicating the possibility of a related sulfate

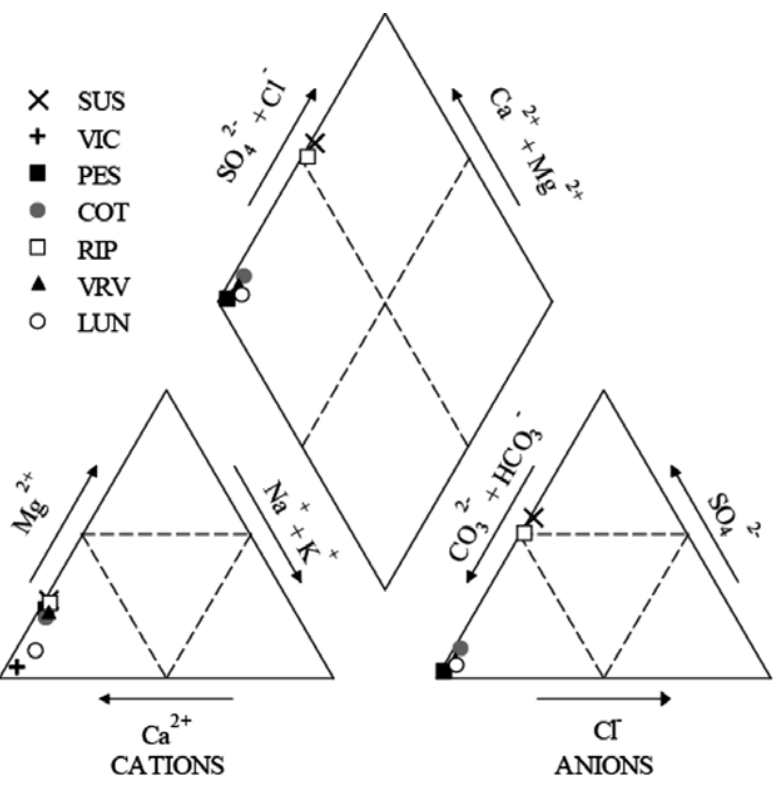

Fig. 4. Piper diagram of major ion concentration of waters in the Rieti Basin area. Values are the mean of the five seasons sampled. For individual season values, refer to Tab. 2 . 
source (Fig. 7). A likely common source is groundwater from the same hydrogeological unit, the Mt. Terminillo thrust belt (Petitta, 2009; Spadoni et al., 2010), where Triassic marine evaporites present in the Mesozoic sedimentary sequence are the dominant source of sulfate (Petitta et al., 2011). The mean $\delta^{18} \mathrm{O}_{\text {sulfate }}$ and $\delta^{34} \mathrm{~S}_{\text {sulfate }}$ of PES, VRV, RIP and LUN also fall within the field of typical values for waters influenced by dissolution of marine Mesozoic evaporites (Fig. 7). The water sampled that falls outside this range, VIC, was in the range of values typical of terrestrial evaporites or sulfate formed by oxidation of reduced sulfur compounds in soil (Krouse and Mayer, 2000).
The analysis of waters from the two lakes, LUN and RIP, provides information on the relationship between surface and groundwater. Previous work noted the connection between the lakes and groundwater (Franceschini et al., 2004; Martarelli et al., 2008), but they do not specifically examine the mechanism or the provenance. The results of this study found that chemical and physical parameters of RIP group closely to SUS, especially conductivity, alkalinity, and dissolved $\mathrm{SO}_{4}^{2-}$ and $\mathrm{Mg}^{2+}$ concentrations. The similar grouping of SUS and RIP also can be seen in stable isotope values $\left(\delta^{2} \mathrm{H}, \delta^{18} \mathrm{O} \delta^{13} \mathrm{C}\right.$ and $\delta^{34} \mathrm{~S}$, Figs. 5-7), demonstrating the magnitude of water flowing from the artificial

Tab. 3. Stable isotope data. Values are expressed in per mil (\%) relative to the standard indicated in the subscript.

\begin{tabular}{|c|c|c|c|c|c|}
\hline & $\delta^{13} \mathrm{CPDB}$ & $\delta^{34} \mathrm{SVCDT}$ & $\delta^{18} \mathrm{O}$-sulfate & $\delta^{18}$ OVSMOW & $\delta^{2} \mathrm{HVSMOW}$ \\
\hline \multicolumn{6}{|l|}{ SUS } \\
\hline 2015-September & -8.8 & 15.5 & 9.6 & -8.4 & -53 \\
\hline 2015-May & -8.9 & 14.9 & 10.0 & -8.6 & -54 \\
\hline 2015-February & -9.0 & 15.4 & 9.3 & -8.4 & -52 \\
\hline 2014-June & -9.0 & & & -8.6 & -53 \\
\hline 2014- July & -10.0 & 15.3 & 10.7 & -8.6 & -53 \\
\hline \multicolumn{6}{|l|}{ VIC } \\
\hline 2015-September & -13.5 & 15.2 & 6.0 & -7.1 & -45 \\
\hline 2015-May & -12.0 & 8.6 & 4.2 & -7.4 & -46 \\
\hline 2015-February & -13.5 & 8.8 & 5.2 & -7.1 & -43 \\
\hline 2014-June & -13.4 & & & -6.9 & -43 \\
\hline 2014- July & -13.8 & -9.9 & -0.7 & -6.9 & -43 \\
\hline \multicolumn{6}{|l|}{ PES } \\
\hline 2015-September & -4.8 & 12.1 & 9.0 & -9.0 & -57 \\
\hline 2015-May & -4.2 & 12.1 & 8.3 & -9.0 & -57 \\
\hline 2015-February & -3.9 & 12.2 & 9.0 & -8.9 & -55 \\
\hline 2014- July & -6.1 & 10.2 & 8.0 & -8.9 & -56 \\
\hline \multicolumn{6}{|l|}{$\mathrm{COT}$} \\
\hline 2015-September & 2.9 & 16.9 & 10.6 & -8.9 & -57 \\
\hline 2015-May & 4.7 & 17.2 & 10.2 & -9.0 & -58 \\
\hline 2015-February & 4.1 & 17.0 & 9.9 & -9.0 & -56 \\
\hline \multicolumn{6}{|l|}{ RIP } \\
\hline 2015-September & -7.7 & 15.8 & 9.3 & -7.7 & -49 \\
\hline 2015-May & -8.8 & 15.3 & 9.5 & -8.2 & -52 \\
\hline 2015-February & -9.2 & 15.1 & 9.4 & -8.2 & -50 \\
\hline 2014-June & -8.7 & & & -7.7 & -48 \\
\hline 2014- July & -10.7 & 15.3 & 10.8 & -7.7 & -48 \\
\hline \multicolumn{6}{|l|}{ LUN } \\
\hline 2015-September & -8.9 & 14.4 & 7.4 & -5.3 & -37 \\
\hline 2015-May & -9.5 & 12.2 & 7.7 & -6.0 & -41 \\
\hline 2015-February & -12.0 & 12.3 & 9.3 & -7.0 & -44 \\
\hline 2014-June & -11.2 & & & -6.3 & -40 \\
\hline 2014- July & -13.9 & 11.1 & 6.8 & -6.3 & -40 \\
\hline \multicolumn{6}{|l|}{ VRV } \\
\hline 2015-September & -3.1 & 14.5 & 10.0 & -8.7 & -56 \\
\hline 2015-May & -4.1 & 9.1 & 9.2 & -8.7 & -56 \\
\hline 2015-February & -6.6 & 9.2 & 8.5 & -8.1 & -50 \\
\hline 2014- July & -4.7 & 13.0 & 8.5 & -8.7 & -55 \\
\hline \multicolumn{6}{|c|}{ Rain Gauges - Spadoni et al. (2010) } \\
\hline \multicolumn{6}{|c|}{ Elevation } \\
\hline 378.0 & & & & -6.0 & -36 \\
\hline 1375.0 & & & & -8.2 & -53 \\
\hline
\end{tabular}


channel diverting SUS water into RIP. The concentrations of the conservative ions $\mathrm{Na}^{+}, \mathrm{K}^{+}$, and $\mathrm{Cl}^{-}$(Tab. 2), however, are slightly higher in RIP than SUS and the $\delta^{18} \mathrm{O}$ and $\delta^{2} \mathrm{H}$ are heavier, suggesting dilution by another minor compo- nent. The channel connecting LUN to RIP was not flowing or contributing significantly during the sampling period, exhibited by the lakes' markedly different chemistries in most parameters. The high water table in this part of the

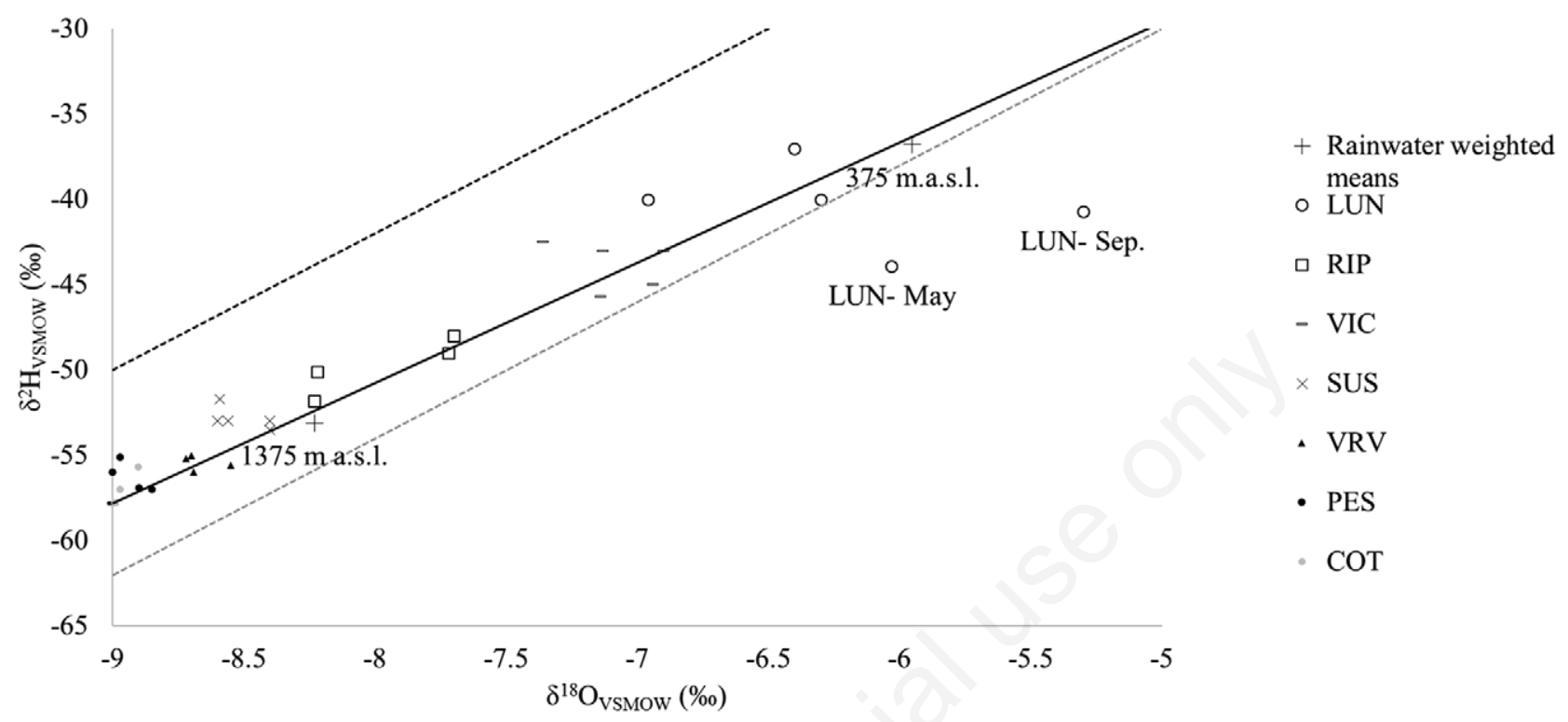

Fig. 5. Oxygen and Hydrogen isotope composition of waters in the Rieti Basin and Velino River Valley. MMWL, cIMWL (Longinelli and Selmo, 2003), and GMWL, are the Mediterranean Meteoric Water Line, central Italian Meteoric Water Line, and the Global Meteoric Water Line, respectively, and from top to bottom. Rainwater samples are from locations within the Rieti Basin and surrounding mountains from Spadoni et al. (2010). Month is indicated for LUN samples that fall below the meteoric water line.

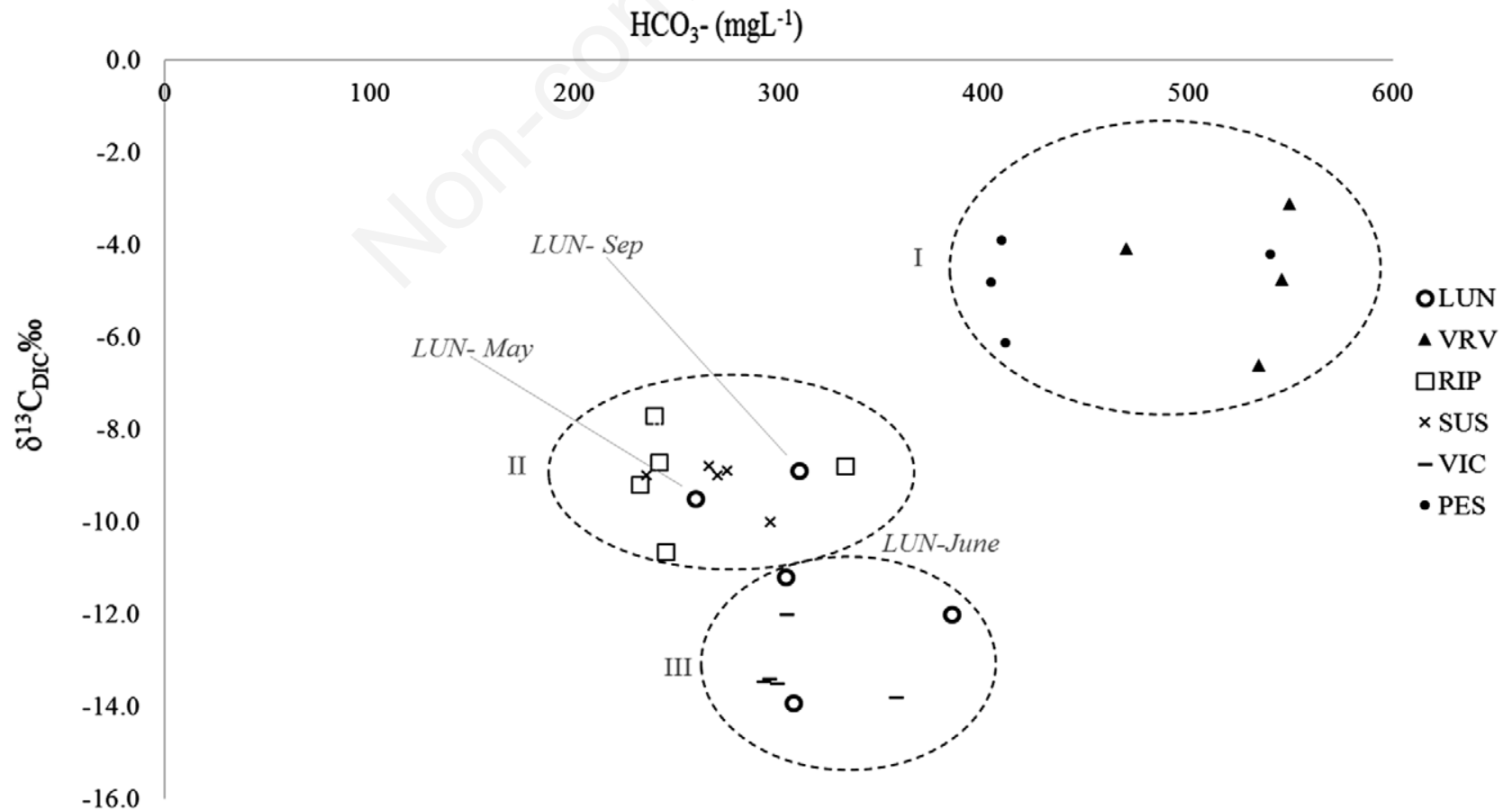

Fig. 6. Bicarbonate concentration versus carbon isotope composition of dissolved inorganic $\mathrm{C}$ in sampled waters. Major groupings, I, II, and III, are denoted by the dashed circles and described in the text. LUN sample months that are outside the groupings are labeled. 
plain, varying between 1 and $4 \mathrm{~m}$ below the ground surface (Martarelli et al., 2008) links both lakes to the shallow aquifer within the plain (Fig. 8). The relative importance of this groundwater through the low-permeability sediments can be estimated by examining the chemical data and modeling the mixing of sampled waters using PHREEQC. The results show that the chemistry of RIP can be produced by mixing $80 \%$ SUS and 20\% LUN water (Tab. 2). LUN was used as a representative of the shallow alluvial aquifer because this water was not sampled and because LUN receives the majority of its water from local recharge and the shallow plain aquifer. LUN water chemistry was similar to the alluvial spring, VIC, in most parameters but the major ion concentrations are slightly greater than the spring. This suggests lake water evaporation and/or a minor contribution to the plain aquifer of the SUS-type groundwater. Field surveys of the LUN perimeter temperature and flow conducted during this study found an absence of relatively colder water or anomalies. This was evidence for the lack of a point source of surface flow or groundwater contribution to the lake. The piezometric data collected by Martarelli et al. (2008) showed that the groundwater table decreases from SUS in the direction of LUN, so a percentage of this groundwater may contribute to the plain aquifer but the low permeability of the lacustrine unit surrounding LUN likely prevents a large conveyance.

\section{Effect of season on waters sampled}

LUN is an interesting case because two of the samples (May and September 2015) have $\delta^{13} \mathrm{C}_{\text {DIC }}$ values that group with SUS and RIP, where the other samples (June and July 2014, February 2015) plot separately (Fig. 6). A scenario where groundwater represented by SUS is feeding into LUN during this period does not agree with the stable isotopic composition of $\delta^{18} \mathrm{O}$ and $\delta^{2} \mathrm{H}$ in LUN (Fig. 5). The dissimilar major ion data also does not support this (Fig. 4), as samples from LUN do not exhibit elevated $\mathrm{SO}_{4}{ }^{2-}$, another chemical tracer of groundwater discharging at SUS. Lake metabolism and primary productivity also play a role in changing the isotope signature of the DIC pool (Bade et al., 2004; Myrbo and Shapley, 2006). The saturation indices with respect to calcite $\left(\mathrm{SI}_{\text {calcite }}\right)$ in LUN show saturation $\left(0<\mathrm{SI}_{\text {calcite }}<1\right)$ during all months sampled. A large change in lake productivity would consume $\mathrm{CO}_{2}$ and drive lake carbonate equilibrium towards lower saturation with respect to calcite (Profft and Stutter, 1993; Wetzel, 2001). The $\mathrm{SI}_{\text {calcite }}$ values of LUN in May and September, however, do not display a shift towards lower values (Tab. 2). The seasonal shift of LUN isotopic values, then, is likely related to a change in relative contributions of watershed, or surface water, DIC to LUN, instead of a major change in primary productivity.

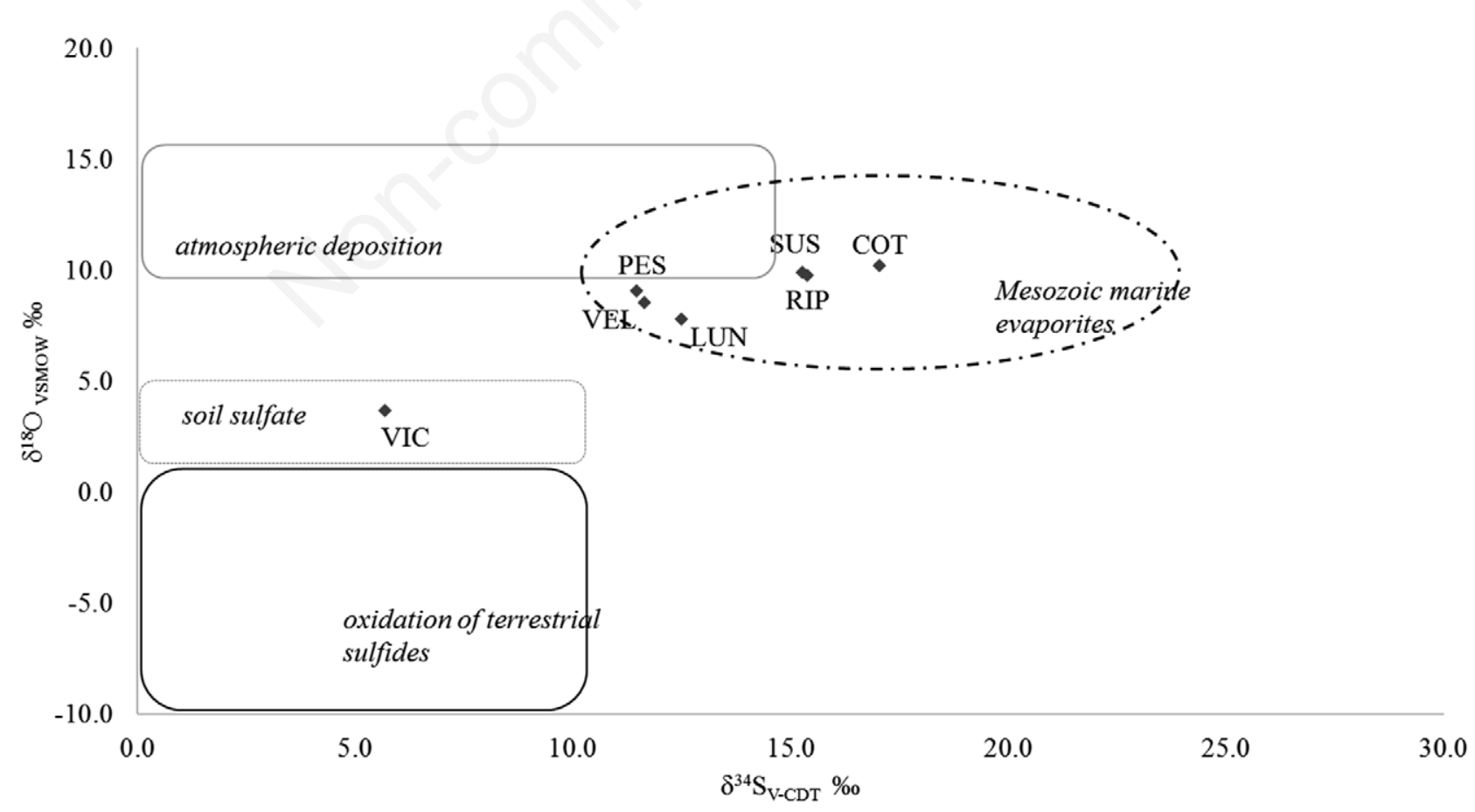

Fig. 7. Sulfur and oxygen isotope composition of sulfate in waters of the study area. Plotted values are the means of the four seasons sampled. Fields indicate typical ranges in values of sulfate from terrestrial sources, atmospheric sulfate, soil sulfate, and from marine evaporites (Modified after Mayer, 2005; 67-81, Fig. 1; with permission). 
In 2015, the months sampled (May and September) fall into a period of above average temperature and below-average precipitation for this region (Supplementary Tabs. 1 and 2). The previous summer (June and July 2014) and prior months experienced above-average precipitation. Temperature during the summer of 2015 (May-September) was also above average every month. This suggests that the most noticeable difference between the two years for the lakes was the water supply and degree of potential evaporation and evapotranspiration. The $\delta^{18} \mathrm{O}$ and $\delta^{2} \mathrm{H}$ values support this hypothesis. The May and September 2015 LUN samples plot below the cIMWL (slope=7.15) on a line with markedly lower slope (3.9). This value falls within the range (3.5 to 6$)$ of surface water evaporation lines (Gourcy

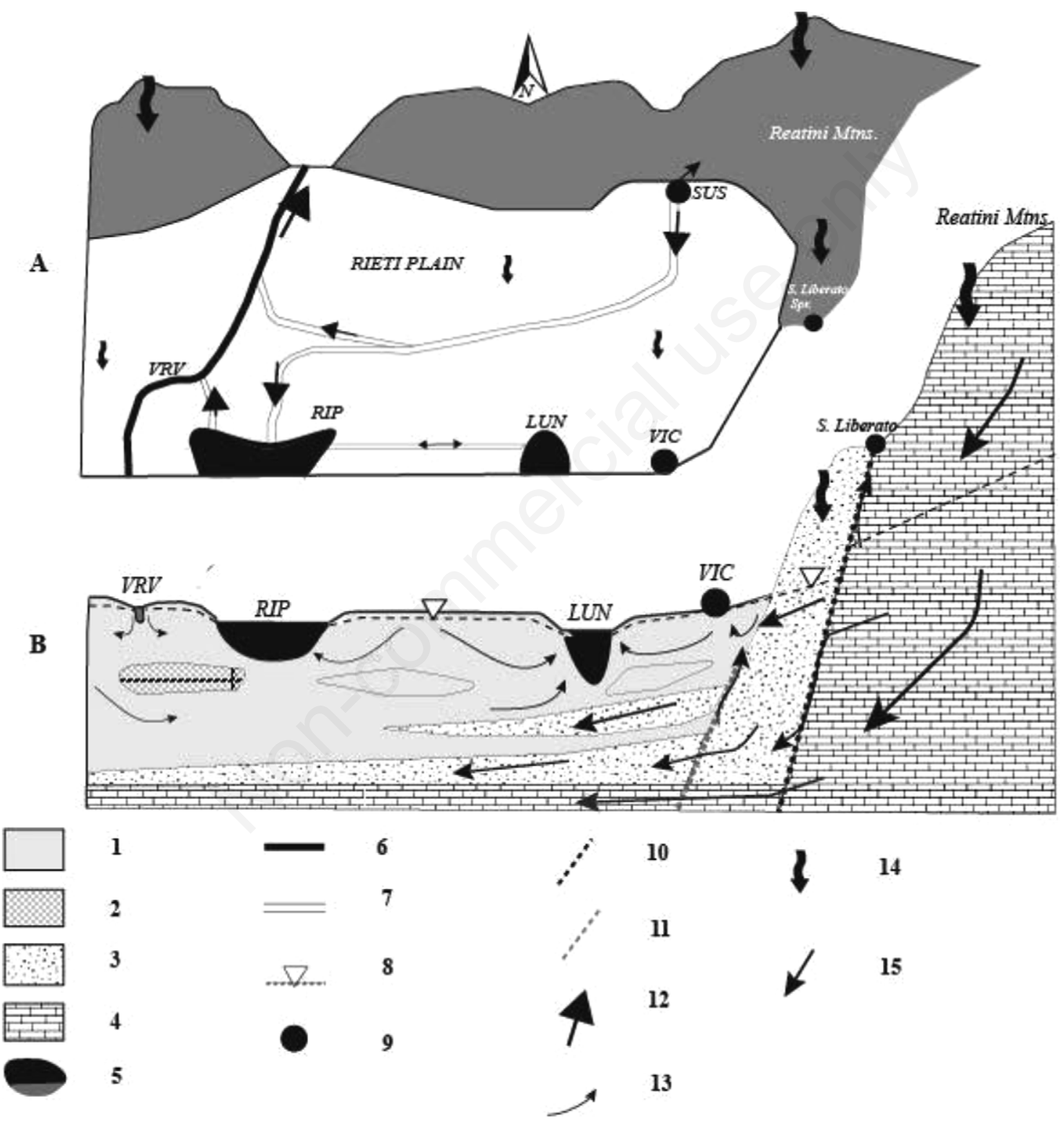

Fig. 8. Conceptual model of groundwater and surface water flow in the northern sector of the Rieti Plain. Drawing is not made to scale but as relative orientation. A) Map-view of the plain. B) Cross-section view. 1, Plain-filling fluvial and lacustrine deposits (Holocene); 2, lenses of peat and peaty clays (Late Pleistocene- Holocene); 3, conglomeratic alluvial deposits and braided gravels (Pliocene- Pleistocene); 4, carbonate bedrock (Mesozoic) and regional aquifer; 5, lakes (overhead and cross-sectional view); 6, Velino River; 7, manmade waterways or canals; 8 , water table; 9 , major spring; 10, Eastern boundary normal fault; 11, buried normal fault; 12 , water flow in surface water courses - arrow size is relative to flow; 13, groundwater flow in low-permeability units; 14, aquifer recharge - size of arrow corresponds to potential infiltration; 15, groundwater flow paths through major aquifers. 
and Brenot, 2011; Gat, 1981). The June and July 2014 samples plot close to or above the line (Fig. 5). The similarity in $\delta^{18} \mathrm{O}$ and $\delta^{2} \mathrm{H}$ values between LUN and VIC during the high-precipitation year suggests that both receive significant contributions from local recharge within the plain. RIP did not display the same evaporation signal, with all samples clustered around the meteoric water line.

The carbon isotope values respond to seasonal changes through several mechanisms. With apparently less contribution from the alluvial groundwater and more time for the lake water to exchange with atmospheric $\mathrm{CO}_{2}$ (atmospheric $\delta^{13} \mathrm{C}_{\text {DIC }}$ values $=-7 \%$, Clark and Fritz, 1997), these low-precipitation samples (May and September 2015) are more enriched and approach $-7 \%$. Li et al. (2011) found a similar response in lakes in southwestern China, although this region in Asia experiences opposite timing of wet and dry seasons than in central Italy. The July 2014 sample could also be anomalously depleted for warm-season $\delta^{13} \mathrm{C}_{\mathrm{DIC}}$ in LUN because above-average precipitation brought increased runoff and a greater flux of soil DIC $\left(\delta^{13} \mathrm{C}_{\mathrm{DIC}}\right.$ values $\sim 23 \%$, Clark and Fritz, 1997) to the lake.

The greatest seasonal changes in $\delta^{18} \mathrm{O}_{\text {sulfate }}$ and $\delta^{34} \mathrm{~S}_{\text {sulfate }}$ were observed in the samples LUN and VRV as well as the spring located within the plain, VIC. All other samples showed variability from season to season of less than 1-2 $\%$. The concentration of sulfate in all the samples, however, did not change substantially among seasons (Tab. 2). This could indicate that the influence of anaerobic bacteria seasonally metabolizing sulfate is more important in some samples. Otherwise, a change in flux water containing soil particles where these microbes proliferate causes the isotope values to change during wetter periods (Jedrysek, 2005). The influence of sulfate in fertilizers applied to crops in this area should not be disregarded (Vitòria et al., 2004), nor should the potential influence of atmospheric deposition of sulfate (Krouse and Mayer, 2000). The strong correlation in LUN between nitrate and sulfate concentrations (Fig. 3a) suggests that sulfate inputs may be related to fertilizer application or runoff of soil into the lake.

\section{Sensitivity to meteorological parameters}

The effect of different weather conditions, and potentially past and future climate, on lake physio-chemical parameters was investigated using correlation analysis (Figs. 2 and 3 ) and also by identifying seasonal shifts in some stable isotope values (Figs. 5 and 6).

The high coefficient values for monthly mean air temperature and water temperature in LUN (0.92) versus lower in RIP (0.64) can be related to the hypothesized longer residence time of water in LUN. If this is the case, then other parameters, such as total dissolved solids (TDS) or accumulation of contaminants, will also be higher in LUN compared to RIP and may also be more sensitive to outside forcing. The negative correlation co- efficients between precipitation and air temperature in both lakes is likely a consequence of the Mediterranean climate in this region of Italy, where the majority of rain and snow fall during the cold months. Alkalinity is greater in both lakes during colder periods, likely because of increased delivery of dissolved ions, particularly $\mathrm{HCO}_{3}{ }^{-}$and $\mathrm{CO}_{3}{ }^{2-}$, during cold and associated wet months.

The major ion correlations with meteorological parameters (Figs. 2 and 3) also offer insight to lake hydrology during different periods of the year. Nitrate showed strong negative correlation coefficients with temperature in both lakes, suggesting that either wet-season (winter) runoff from surrounding agriculture delivers most of the nitrate to the lakes, or that algal assimilation of nitrate is most intense in the warm months, leaving lower detectable concentrations during warm periods (Wetzel, 2001). These potential explanations, if further investigated, can be utilized in the management and remediation of the eutrophication of these lakes. Although marshy vegetation surrounds much of both lakes, intercepting the irrigation canal-water before it flows in, this system may be less effective at preventing nitrate from entering during the rainy months. In $\mathrm{LUN}, \mathrm{SO}_{4}{ }^{2-}$ and $\mathrm{Ca}^{2+}$ also show significant negative correlation coefficients with respect to temperature. These ions may also be delivered to the lake by a greater flux of water during the wet months.

While there is not sufficient data available to quantify the water budgets for these two lakes, the correlation data and water stable isotope data suggest a substantial difference in one or more of the terms of the budget between them. A simplified water budget in lakes is given by the equation (modified from Rosenberry et al., 2015):

$\Delta \mathrm{V} / \Delta \mathrm{t}=\mathrm{P}-\mathrm{E} \pm \mathrm{SF} \pm \mathrm{GF}$

where $\Delta \mathrm{V} / \Delta \mathrm{t}$ is the change in storage over time, or renewal time, $\mathrm{P}$ is precipitation, $\mathrm{E}$ is evaporation, $\mathrm{SF}$ is surface flow (either into or out of the lake) and GF is groundwater flow (also either in or out of the lake). The mean annual evaporation can be estimated using the equation derived by Dragoni and Valigi (1994) for lakes located in central Italy:

$\mathrm{E}_{\mathrm{m}}=19.007 \mathrm{i}_{\mathrm{m}}^{3.063} \mathrm{~T}_{\mathrm{m}}^{0.486}$

where $E_{m}$ is the monthly evaporation (in $m m$ ), $i_{m}$ is the Thornthwaite insolation monthly index $\left(42^{\circ} \mathrm{N}\right.$ latitude) and $\mathrm{T}_{\mathrm{m}}$ is the monthly average air temperature. The annual mean value of $1059 \mathrm{~mm} \mathrm{yr}^{-1}$ was calculated using monthly temperature over the period of 2003-2015. Mean annual precipitation, calculated by adding monthly totals over each 12-month period, over the same time period is $1010 \mathrm{~mm} \mathrm{yr}^{-1}$. As warmer and drier conditions prevail, a concurrent increase in $\mathrm{E}$ and decrease in $\mathrm{P}$ may lead to a 
further deficit in P compared to E (Fioravanti et al., 2015; Brunetti et al., 2012). The groundwater flow in and out was also assumed equal and opposite solely for the purpose of this estimation. Removing these terms, the 'theoretical renewal time', or the volume of the lake divided by the volume of its outflow (Ambrosetti et al., 2002), was calculated. The volumetric flow rate through the artificial channel from SUS to RIP, measured during May 2015 and September 2015 at $1 \mathrm{~m}^{3} \mathrm{~s}^{-1}$, is the only active surface flow observed in the two-lake system.

Although data for the rate of pumping water out of RIP was not obtained, a daily record of lake surface level from March- December 2014 shows that the level was maintained within $0.2 \mathrm{~m}$, so the volume of outflow was estimated as the volume of this inflow channel water. In this scenario, the rate of water cycling through RIP would cause average renewal time of 11.7 days. This value is low compared with other studies on lake renewal time but it is reflective of the more than two orders of magnitude difference in volume between RIP and these lakes (Ambrosetti et al. 2002; Varekamp, 2003). Without measurable or quantifiable water flowing in or out of LUN, the same estimation was not possible for this lake but a conceptual comparison is now feasible. It is unlikely, based on physical surveys, that significant through-flow for LUN at the surface or even as an unmeasured groundwater component, persists throughout the entire year with near constant discharge as in RIP. This difference in theoretical renewal time yields an explanation for the dissimilarities in chemical parameters observed. This calculated rapid renewal rate in RIP also provides an explanation for the lack of sensitivity of major ions in RIP to air temperature or precipitation (Fig. 3) and lack of seasonal variation in $\delta^{2} \mathrm{H}$, $\delta^{18} \mathrm{O}$, and $\delta^{13} \mathrm{C}_{\text {DIC }}$ values (Figs. 5 and 6). In these parameters, the lake chemistry resembles the spring contributing inflow (SUS), instead of reflecting within-lake processes, such as primary productivity or evaporation. The difference in theoretical renewal time of the lakes also has potentially significant implications for how contaminants, agricultural runoff, and nutrients persist and cycle.

\section{CONCLUSIONS}

This hydrochemical investigation provides information on the provenance of source water for Lake Lungo and Lake Ripasottile and the response of these lakes to seasonal variations in temperature and water supply. Using chemical, isotopic, physical and meteorological data we could show that there is limited connectivity between these two lakes and that they respond independently to local weather conditions. Despite the human landscape modifications of LUN and RIP and their geographical proximity, it was found that nearly all lake chemical parameters were more similar to their primary prospective groundwater influences than to each other. These findings are evidence for hydrochemical investigations as viable approaches in limnological studies when the availability of physical measurements of flow is limited.

The recharge areas and elevations of the springs sampled (SUS and VIC) are separate and distinct, evidenced by the difference in the $\delta^{2} \mathrm{H}$ and $\delta^{18} \mathrm{O}$ of the waters. These observations supported the characterization of these springs as representative of the distinctive source waters to the lakes. RIP, similar to SUS in almost all chemical and isotopic parameters, is sourced primarily from the carbonate aquifer and higher elevation recharge, whereas LUN, along with VIC, is sourced mainly from the alluvial aquifer and local recharge. The conveyance of carbonate aquifer water to RIP, represented by SUS water, is mainly transferred via flow in an artificial channel that discharges into the lake. This creates a faster flow-through regime than in LUN. Seasonal changes in LUN stable isotopes of water also indicate a longer residence time of water in this system compared to RIP. The variable seasonal contribution of groundwater and local recharge to LUN is evident in its hydrochemistry, especially demonstrated by LUN $\delta^{13} \mathrm{C}_{\mathrm{DIC}}$ values.

In the context of Italy's past and future climate, the physio-chemical response of these lakes to changing seasons demonstrates how they may respond to shifting climate trends. If water supply to the lakes decreases in the future because of continuing patterns in lower wet-season precipitation and higher temperatures, there may be significant effects on lake water chemistry and trophic status. To determine the specific effects at RIP, a more frequent sampling campaign may be employed that reflects the fast water renewal rate calculated in this work. LUN showed more sensitivity to changes in seasonal weather parameters, particularly illustrated by the correlation between nitrate concentration and the local air temperature. This should be considered for management of the protected area, especially within the context of increasing agricultural demands on groundwater in the basin and how this demand may grow with a changing climate.

\section{ACKNOWLEDGMENTS}

We would like to thank the Riserva Naturale dei Laghi Lungo e Ripasottile and their employees, especially Paolo Bellezza and Maurizio Sterpi, who helped significantly with sample collection and by providing housing at the field site. The Agenzia Regionale per la Protezione Ambientale della Regione Lazio was also fundamental in this work through their data contribution. Professors Maurizio and Mario Barbieri and Sapienza University of Rome generously contributed with lab space and time for a portion of the sample processing. A portion of funding for this work was provided by the National Science Founda- 
tion grant (GSS-1228126) awarded to Mensing and Noble, and also by the Paul Yaniga Memorial Trust.

\section{REFERENCES}

Ambrosetti W, Barbanti L, Sala N, 2002. Residence time and physical processes in lakes. J. Limnol. 62(Suppl. 1):1-15.

Bade D, Carpenter S, Cole J, 2004. Controls of $813 \mathrm{C}$-DIC in lakes: Geochemistry, lake metabolism, and morphometry. Limnol. Oceanogr. 49:1160-1172.

Bluszcz P, Lucke A, Ohlendorf C, Zolitschka B, 2009. Seasonal dynamics of stable isotopes and element ratios in authigenic calcites during their precipitation and dissolution, Sacrower See (northeastern Germany). J. Limnol. 68:257-273.

Boni C, Bono P, Capelli G, 1986. [Schema idrogeologico dell'Italia central].[Article in Italian]. Mem. Soc. Geol. Ital. 35:991-1012.

Brunetti M, Caloiero T, Coscarelli R, Gullà G, Nanni T, Simolo C, 2012. Precipitation variability and change in the Calabria region (Italy) from a high resolution daily dataset. Int. J. Climatol. 32:57-73.

Capelli G, Mastrorillo L, Mazza R, Petitta M, Baldoni T, Banzato F, Doredana C, Di Salvo C, La Vigna F, Taviani S, Teoli P, 2012. [Carta Idrogeologica del Territorio della Regione Lazio].[Map in Italian]. Regione Lazio, Rome.

Carmody RW, Plummer LN, Busenberg E, Coplen TB, 1998. Methods for collection of dissolved sulfate and sulfide and analysis of their sulfur isotopic composition. U.S. Geological Survey, Open-File Report 97-234: 91 pp.

Carucci V, Petitta M, Aravena R, 2012. Interaction between shallow and deep aquifers in the Tivoli Plain (Central Italy) enhanced by groundwater extraction: A multi-isotope approach and geochemical modeling. Appl. Geochem. 27:266-280.

Cavinato GP, De Cellis PG, 1999. Extensional basins in the tectonically bimodal central Apennines fold-thrust belt, Italy: response to corner flow above a subduction slab in retrograde motion. Geology 27:955-958.

Civita M, Fiorucci A, 2010. The recharge-discharge process of the Peschiera spring system (central Italy). Aqua Mundi 02019:61-178.

Clark I, Fritz P, 1997. Environmental isotopes in hydrogeology. CRC Press/Lewis Publishers, Boca Raton: 328 pp.

Cohen A, 2003. Paleolimnology: the history and evolution of lake systems. Oxford University Press, USA.

Combourieu-Nebout N, Bertini A, Russo-Ermolli E, Peyron O, Klotz S, Montade V, Fauquette S, Allen J, Fusco F, Goring S, Huntley B, Joannin S, Lebreton V, Magri D, Martinetto E, Orain R, Sadori L, 2015. Climate changes in the central Mediterranean and Italian vegetation dynamics since the Pliocene. Rev. Palaeobot. Palynol. 218:127-147.

Costantini E, Dazzi C, Costantini E, Fantappié M, L'Abate G. 2013. Climate and pedoclimate of Italy, p. 19-37. In: E Costantini and C Dazzi (eds.) The soils of Italy. Springer, Dordrecht.

Cosentino D, Cipollari P, Marsili P, Scrocca D, 2010. Geology of the central Apennines: a regional review. J. Virtual Expl. $36: 12$.

Di Matteo L, Dragoni W, 2006. Climate change and water resources in limestone and mountain areas: the case of Firen- zuola Lake (Umbria, Italy), p. 83-33. In: N. Goldscheider, J. Mudry, L. Savoy and F. Zwahlen (eds.), Proceedings of the 8th Conf.on Limestone Hydrogeology.

Dragoni W, Valigi D, 1994. [Contribution to the knowledge of evaporation in lakes of Central Italy].[Article in Italian]. Geologica Romana 30:151-158.

Epstein S, Mayeda T, 1953. Variation of O 18 content of waters from natural sources. Geochim. Cosmochim. 4:213-224.

Fioravanti G, Piervitali E, Desiato F, 2015. Recent changes of temperature extremes over Italy: an index-based analysis. Theor. Appl. Climatol. 123:473-486.

Fiorillo F, Petitta M, Preziosi E, Rusi S, Esposito L, Tallini M, 2015. Long-term trend and fluctuations of karst spring discharge in a Mediterranean area (central-southern Italy). Environ. Earth Sci. 74:153-172.

Franceschini S, Damiani G, Venanzi D, Fabiani S, Schirone B, Mancini L, 2004. Environmental quality of the protected area of Lungo and Ripasottile lakes (Rieti, Italy). Rapporti ISTISAN 04/39.

Giesemann A, Jäger HJ, Norman AL, Krouse HR, Brand WA, 1994. Online sulfur-isotope determination using an elemental analyzer coupled to a mass spectrometer. Anal. Chem. 66:2816-2819.

Gourcy L, Brenot A. 2011. Multiple environmental tracers for a better understanding of water flux in a wetland area ( $\mathrm{La}$ Bassée, France). Appl. Geochem. 26:2147-2158.

Grassineau NV, Mattey DP, Lowry D. 2001. Sulfur isotope analysis of sulfide and sulfate minerals by continuous flowisotope ratio mass spectrometry. Anal. Chem. 73:220-225.

Harris D, Porter LK, Paul EA, 1997. Continuous Flow Isotope Ratio Mass Spectrometry of Carbon Dioxide Trapped as Strontium Carbonate. Commun. Soil Sci. Plan. 28:747-757.

Jedrysek M. 2005. S-O-C isotopic picture of sulphate-methanecarbonate system in freshwater lakes from Poland. A review. Environ. Chem. Lett. 3:100-112.

Kornexl BE, Gehre M, Höffling R, Werner RA, 1999. On-line d180 measurement of organic and inorganic substances. Rapid Commun. Mass. Sp. 13:1685-1693.

Krouse HR, Mayer B, 2000. Sulphur and oxygen isotopes in sulphate, p. 195-231. In: P.G. Cook and A.L. Herczeg (eds.), Environmental tracers in subsurface hydrology. Springer, New York.

LaBaugh J, Rosenberry D, 2008. Introduction and Characteristics of flow, p. 1-38. In: D.O. Rosenberry and J.W. LaBaugh (eds.), Field techniques for estimating water fluxes between surface water and ground water: U.S. Geological Survey Techniques and Methods 4-D2.

Leone A, 2004. [Ambiente e territorio agroforestale: line guida per la pianificazione sostenibile e gli studi di impatto ambientale].[Book in Italian]. Franco Angeli, Milan.

Li SL, Liu CQ, Tao FX, Lang YC, Han GL, 2005. Carbon biogeochemistry of ground water, Guiyang, Southwest China. Groundwater 43:494-499.

Longinelli A, Selmo E, 2003. Isotopic composition of precipitation in Italy: a first overall map. J. Hydrol. 270:75-88.

Massarutto A, 1999. Agriculture, water resources and water policies in Italy. Working paper 33-99. Fondazione ENI E. Mattei, Milan.

Martarelli L, Petitta M, Scalise A, Silvi A, 2008. [Cartografia idrogeologica sperimentale della Piana Reatina (Lazio)].[Ar- 
ticle in Italian]. Mem. Descr. Carta Geol. It. 81:137-156.

Martin T, Creed J, Long L, 1994. Method 200.2: sample preparation procedure for spectrochemical determination of total recoverable elements. In: C.K. Smoley (ed.) Methods for the Determination of Metals in Environmental Samples. Environmental Monitoring Systems Laboratory, U.S. Environmental Protection Agency, Cincinnati, OH, USA.

Maxfield R, Mindak B, 1985. EPA Method Study 27, Method 200.7: Trace Metals by ICP. US Environmental Protection Agency, Office of Research and Development, Environmental Monitoring and Support Laboratory.

Mayer B, 2005. Assessing sources and transformations of sulphate and nitrate in the hydrosphere using isotope techniques, p. 67-89. In: P.K. Aggarwal, J.R. Gat and F.O. Froehlich (eds.), Isotopes in the water cycle: past present future of a developing science. Springer, Dordrecht.

Mensing SA, Tunno I, Sagnotti L, Florindo F, Noble P, Archer C, Zimmerman S, Pavón-Carrasco FJ, Cifani G, Passigli S, Piovesan G, 2015. 2700 years of Mediterranean environmental change in central Italy: a synthesis of sedimentary and cultural records to interpret past impacts of climate on society. Quaternary Sci. Rev. 116:72-94.

Morrison J, Brockwell T, Merren T, Fourel F, Phillips AM, 2001. On-line high-precision stable hydrogen isotopic analyses on nanoliter water samples. Anal. Chem. 73:3570-3575.

Myrbo A, Shapley M, 2006. Seasonal water-column dynamics of dissolved inorganic carbon stable isotopic compositions $\left(\delta^{13} \mathrm{C}_{\mathrm{DIC}}\right)$ in small hardwater lakes in Minnesota and Montana. Geochim. Cosmochim. Ac. 70:2699-2714.

Parkhurst D, Appelo C, 1999. User's guide to PHREEQC (version 2)- A computer program for speciation, batch-reaction, one-dimensional transport, and inverse geochemical calculations: U.S. Geological Survey Water-Resources Investigations Report 99-4259: 312 pp.

Perini M, Camin F, Corradini F, Obertegger U, 2009. Use of $\delta^{18} \mathrm{O}$ in the interpretation of hydrological dynamics in lakes. J. Limnol. 68:174-182.

Petitta M, 2009. Hydrogeology of the middle valley of the Velino River and of the S. Vittorino Plain (Rieti, Central Italy). Ital. J. Eng. Geol. Environ. 1-157:181.

Petitta M, Primavera P, Tuccimei P, Aravena R, 2011. Interaction between deep and shallow groundwater systems in areas affected by Quaternary tectonics (Central Italy): a geochemical and isotope approach. Environ. Earth Sci. 63:11-30.

Pfaff J, 1993. Method 300.0 Determination of inorganic anions by ion chromatography. US Environmental Protection Agency, Office of Research and Development, Environmental Monitoring Systems Laboratory.
Priscu J, Dodds W, 1988. An inexpensive device for sampling large volumes of lake water from discrete depths. Freshwater Biol. 20:113-115.

Riccardi R, 2006. [Studi geografici sui laghi Lungo, Ripasottile e Ventina]. Quaderni della Riserva Naturale dei laghi Lungo e Ripasottile 1-47.

Rosenberry D, Lewandowski J, 2015. Groundwater-the disregarded component in lake water and nutrient budgets. Part 1: effects of groundwater on hydrology. Hydrol. Process. 29:2895-2921.

Sacks L, Lee T, Swancar A, 2014. The suitability of a simplified isotope-balance approach to quantify transient groundwater-lake interactions over a decade with climatic extremes. J. Hydrol. 519:3042-3053.

Sappa G, Barbieri, M, Ergul S, Ferranti F, 2012. Hydrogeological conceptual model of groundwater from carbonate aquifers using environmental isotopes $\left(\delta^{18} \mathrm{O}, \delta^{2} \mathrm{H}\right)$ and chemical tracers: a case study in southern Latium Region, Central Italy. J. Water. Resour. Prot. 4:695-716.

Spadoni M, Brilli M, Giustini F, Petitta M, 2010. Using GIS for modelling the impact of current climate trend on the recharge area of the S. Susanna spring (central Apennines, Italy). Hydrol. Process. 24:50-64.

Tallini M, Falcone R, Carucci V, Falgiani A, Parisse B, Petitta M, 2014. Isotope hydrology and geochemical modeling: new insights into the recharge processes and water-rock interactions of a fissured carbonate aquifer (Gran Sasso, central Italy). Environ. Earth Sci. 72:4957-497.

Tassi F, Cabassi J, Rouwet D, Paslozzi R, Marcelli M, Quartararo M, Capecchiacci F, Nocentini M, Vaselli O, 2012. Water and dissolved gas geochemistry of the monomictic Paterno sinkhole (Central Italy). J. Limnol. 71:245-260.

Usdowski E, Hoefs J, Menschel G, 1979. Relationship between $13 \mathrm{C}$ and $18 \mathrm{O}$ fractionation and changes in major element composition in a recent calcite-depositing spring - A model of chemical variations with inorganic $\mathrm{CaCO} 3$ precipitation. Earth Planet. Sci. Lett. 42:267-276.

Varecamp J, 2003. Lake contamination models for evolution towards steady state. J. Limnol. 62(Suppl.1):67-72.

Vitòria L, Otero N, Soler A, Canals A. 2004. Fertilizer characterization: isotopic data (N, S, O, C, and Sr). Environ. Sci. Technol. 38:3254-3262.

Wetzel R, 2001. Limnology: lake and river ecosystems. 3. Academic Press, San Diego: 1006 pp.

Zuppi GM, Bortolami GC, 1982. Hydrogeology: a privileged field for environmental stable isotopes applications. Some Italian examples. Rend. Soc. Ital. Mineral. Petrol. 38:11971212. 